\title{
Induction by HMBA and DMSO of genes introduced into mouse erythroleukemia and other cell lines by transient transfection
}

\author{
Paul L. Campbell, Andreas E. Kulozik, Jean P. Woodham, and Richard W. Jones \\ Institute of Molecular Medicine, John Radcliffe Hospital, Headington, Oxford, OX3 9DU, UK
}

\begin{abstract}
We have found rapid induction of various genes, including human globin genes, in response to hexamethylene bisacetamide (HMBA) and dimethyl sulfoxide (DMSO) in transiently transfected cells. In mouse erythroleukemia cells (MELCs), this effect is detected within $1 \mathrm{hr}$ of exposure of the cells to inducer before the endogenous mouse globin genes are induced. It does not require protein synthesis and is reversed if the inducer is removed. This and other evidence suggest that the mechanism involves a change in activity of a factor intimately involved with transcription, probably as a result of post-translational modification. As such, it may represent an early triggering event in terminal differentiation, and its relevance to the expression of human globin genes in stable transfectants and to induction of the mouse globin genes is discussed. Other cell lines (K562 and NSO) also show this response, which may therefore involve a ubiquitous mechanism. We also found that HMBA depresses the expression of endogenous globin genes in K562, the opposite of this differentiation inducer's effect on MELC.
\end{abstract}

[Key Words: Induction; differentiation; MEL; globin; HMBA]

Received September 13, 1989; revised version accepted March 12, 1990.

Hexamethylene bisacetamide (HMBA) induces terminal differentiation in a variety of cell lines (Marks and Rifkind 1989). Of these, mouse erythroleukemia cells (MELCs), a virally transformed cell line that is blocked on the path to terminal erythroid differentiation, has attracted attention as a model for the study of both globin gene expression and terminal differentiation (Friend et al. 1971; Marks and Rifkind 1989). The potential for terminal differentiation is retained indefinitely by these cells and can be expressed by exposure to a variety of inducers. Among the changes in gene expression that accompany this process is the induced transcription of the

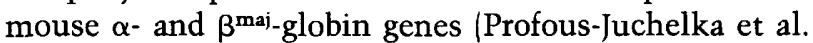
1983; Ganguly and Skoultchi 1985|, seen only after a lag of between 12 and $24 \mathrm{hr}$ (Salditt-Georgieff et al. 1984; Sheffery et al. 1984). The intervening time is occupied by a complex series of events that may include changes that are prerequisites for globin gene expression. For example, induction is followed rapidly by changes in inositol metabolites (Faletto et al. 1985) and in the expression of a number of proto-oncogenes (Ramsay et al. 1986). Constitutive expression of one of these proto-oncogenes, c-myc, can block terminal differentiation (Coppola and Cole 1986). In addition, cellular DNA undergoes a cyclical change in cytosine methylation (Razin et al. 1988). These early events occur at a time when the differentiation process requires the continued presence of inducer, but after 8-12 hr, the cells reach a committed state, in which terminal differentiation continues, and the mouse globin genes are expressed in the absence of inducer (Gusella et al. 1976; Chen et al. 1982).

MELCs have provided a useful system for studies on the regulation of human globin genes. Introduction of part of human chromosome 11 or all of 16 into MELCs leads to induced expression of the $\beta$ - or $\alpha$-globin genes at levels comparable with those of the endogenous mouse genes (Deisseroth and Hendrich 1979; Nandi et al. 1988). Stable transfectants containing the human $\alpha$ - or $\beta$-genes give low levels of expression, and although the $\beta$-globin gene is inducible, the $\alpha$-globin gene is constitutive /Chao et al. 1983; Wright et al. 1983, 1984; Charnay et al. 1984). The more recent identification of a dominant control region (DCR) sited at the $5^{\prime}$ end of the $\beta$-globin gene cluster /Grosveld et al. 1987; Ryan et al. 1989b; Talbot et al. 1989; Tuan et al. 1989; van Assendelft et al. 1989 ) has allowed high levels of human $\beta$-globin expression, equal to those of the endogenous mouse genes, when it is linked to the human gene in MELC stable transfectants (Talbot et al. 1989). Although the DCR provides a tissue-specific level of regulation, it is developmental stage independent (Tuan et al. 1989), and regulatory sequences closer to the globin genes may be responsible for stage-specific expression (Kollias et al. 
1986; Chada et al. 1987; Trudel et al. 1987). Regulatory sequences lying $5^{\prime}$ and $3^{\prime}$ close to the human $\beta$ gene have been identified in stable MELC transfectants and in transgenic mice (Behringer et al. 1987; Kollias et al. 1987; Trudel et al. 1987; Antoniou et al. 1988). The involvement of both distant and local sequences in the regulation of the human $\alpha$-globin genes remains more of an enigma. However, the ability of the $\beta$-globin cluster DCR to support high levels of tissue-specific expression of the $\alpha$-globin gene in transgenic mice (Hanscombe et al. 1989; Ryan et al. 1989a) suggests the presence of an analogous sequence in the human $\alpha$-globin gene cluster (Higgs et al. 1989). The question of involvement of sequences close to the $\alpha$-globin genes remains more open.

We used electroporation to transfect MELCs transiently. Applied to the process of terminal differentiation, transient transfection may allow identification of individual events on the pathway to terminal differentiation and globin gene expression. We describe a rapid, labile stimulation of transcription of a variety of apparently unrelated genes and artificial promoters following exposure to inducer. This is independent of protein synthesis and is likely to involve post-translational modification.

\section{Results}

Dependence of expression on plasmid concentration

Preliminary experiments showed that the human $\alpha$ - and $\beta$-globin genes could be rapidly induced following transient transfection of MELCs. However, it was important to establish that their expression did not saturate and that induction did not vary over the range of plasmid concentrations used for electroporation.

Uninduced MELCs were transfected with the human $\alpha_{1}$-globin gene (pSPN $\left.\alpha N\right)$ at a number of DNA concentrations and grown with or without inducer $15 \mathrm{~mm}$ HMBA) for $6 \mathrm{hr}$ before harvesting (Fig. 1A). At input DNA concentrations where the human $\alpha$-globin transcript was detected, induction was associated with a 10to 20-fold increase in human transcript. As expected, there is no evidence for induction of the mouse $\alpha$-globin genes by $6 \mathrm{hr}$ after exposure to HMBA (Salditt-Georgieff et al. 1984; Sheffery et al. 1984). The accumulation of human $\alpha$ transcript was not related in a simple manner to the DNA concentration used for electroporation, and there was a threshold of $20-50 \mu \mathrm{g} / \mathrm{ml}$ below which either transfection or expression appeared to be inhibited. A similar result was obtained with the human $\beta$-globin

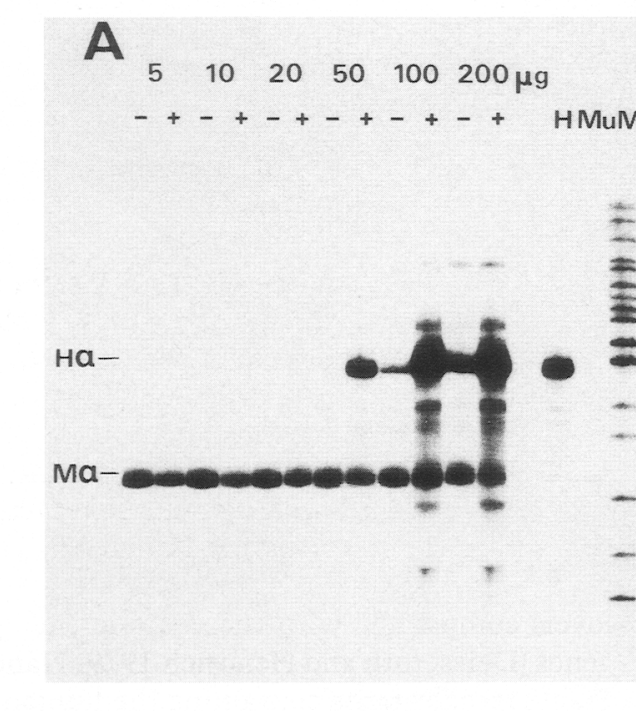

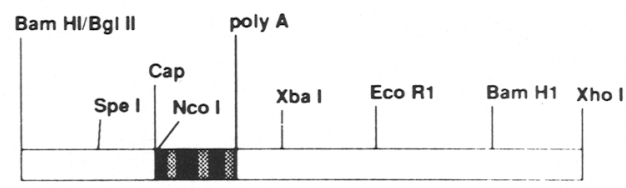

Human $\alpha 1$-globin Gene
B $1020 \quad 50 \quad 100200 \mu \mathrm{g}$
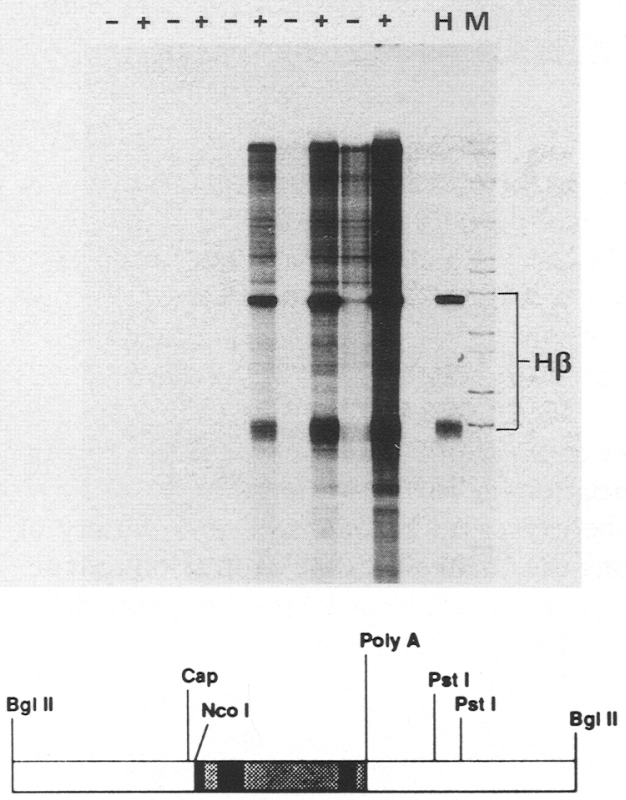

Human $\beta$-globin Gene

Figure 1. Human globin gene expression following electroporation of MELCs at a number of plasmid concentrations. MELCs were electroporated in the presence of $5-200 \mu \mathrm{g} / \mathrm{ml} \mathrm{pSPN} \alpha \mathrm{N}(A)$ or $10-200 \mu \mathrm{g} / \mathrm{ml} \mathrm{pSPN} \beta N(B)$. Transfected cells were divided and grown with ( + ) or without $(-15 \mathrm{mM}$ HMBA for $6 \mathrm{hr}(A)$ or $4 \mathrm{hr}(B)$ before harvesting and RNA analysis. $(A)$ Five micrograms of total RNA and samples of human $(\mathrm{H})$ and mouse $(\mathrm{Mu})$ bone marrow RNA hybridized with human (pSP6 $\alpha$ 132) and mouse (pSP64 $\Delta \mathrm{M} \alpha) \alpha$-globin probes gave the expected protected fragments, representing human $(\mathrm{H} \alpha)$ and mouse (M $\alpha) \alpha$-globin mRNA. The molecular weight markers (M) in this and subsequent experiments are end-labeled HpaII-digested pBR322. Below is shown the genomic DNA insert containing the human $\alpha_{1}$-globin gene in pSPN $\alpha \mathrm{N}$. $(B)$ Twenty-microgram samples of total RNA and a sample of human bone marrow RNA (H) were hybridized with a human $\beta$-globin probe (pSP64H $\beta 142$ ) to give 142- and 210 -bp fragments protected by human $\beta$ mRNA (H $\beta$ ). Below is shown the genomic DNA insert containing the human $\beta$-globin gene in pSPN $\beta N$. 
gene (pSPN $\beta N$; Fig. 1B). By 4 hr after exposure of transfected cells to inducer, the amount of human $\beta$ transcript increased 10- to 20 -fold over that in uninduced cells. As with the human $\alpha$-globin gene, there was a threshold to expression between 20 and $50 \mu \mathrm{g} / \mathrm{ml}$ of DNA.

Because this threshold could be explained by either specific or nonspecific binding of plasmid to sites that inhibit transfection or expression, the effect of cotransfecting with carrier DNA was examined (Fig. 2). MELCs were transfected at concentrations of $\mathrm{pSPN} \alpha \mathrm{N}$ ranging from 2 to $100 \mu \mathrm{g} / \mathrm{ml}$, but with the total DNA concentration maintained at $100 \mu \mathrm{g} / \mathrm{ml}$ by the inclusion of vector DNA (pSPNKN). Cells were transfected in duplicate at each pSPN $\alpha \mathrm{N}$ concentration and grown in the presence (Fig. 2B) or absence (Fig. 2A) of inducer. Radioactivity in
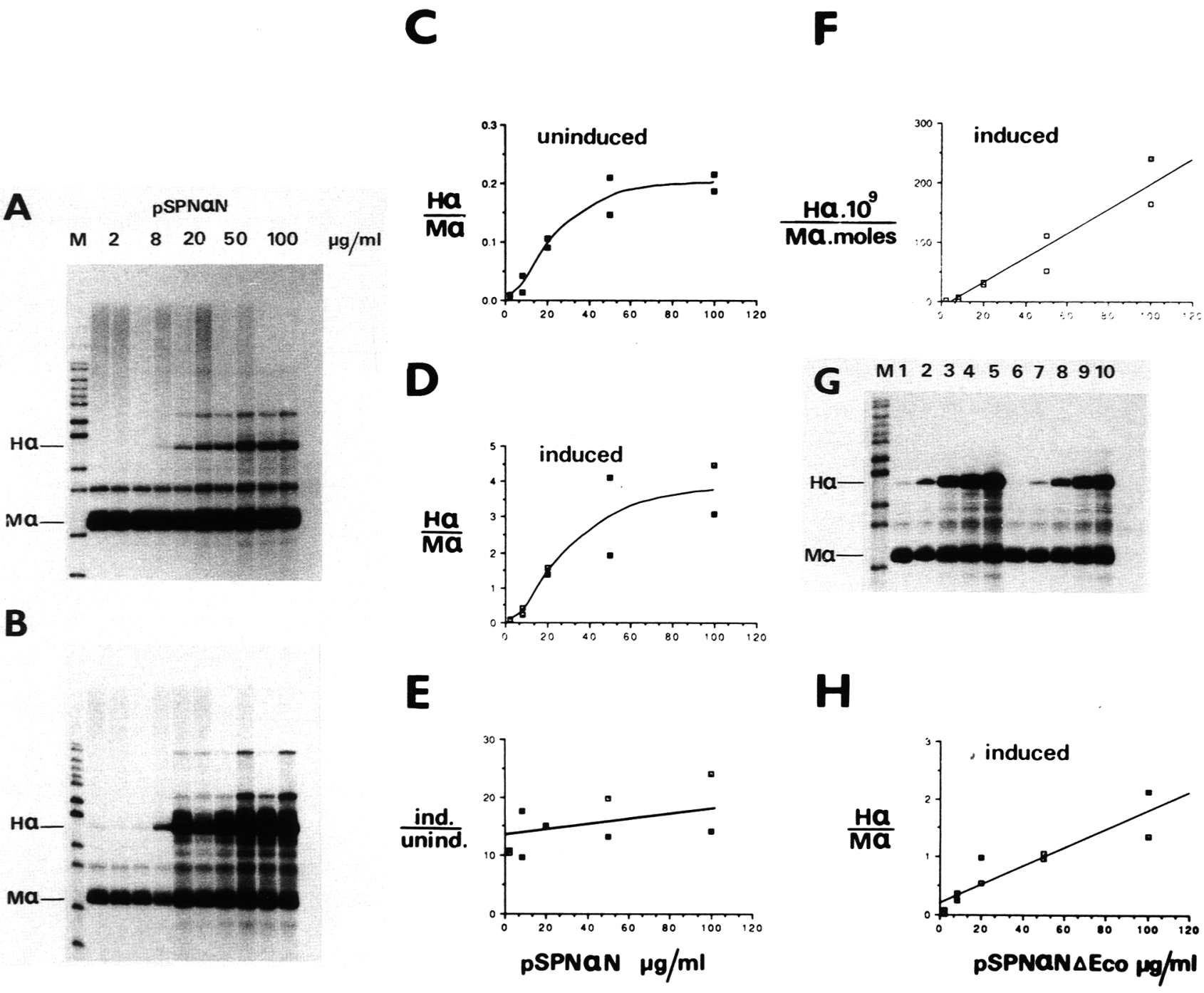

Figure 2. Human $\alpha$-globin expression following electroporation of MELCs at different concentrations of pSPN $\alpha \mathrm{N}$ in the presence of carrier DNA. $(A$ and $B)$ MELCs were electroporated at a constant plasmid concentration of $100 \mu \mathrm{g} / \mathrm{ml}$ of which $2-100 \mu \mathrm{g} / \mathrm{ml} \mathrm{was}$ made up of pSPN $\alpha \mathrm{N}$ and the remainder of pSPNKN (plasmid vector). Duplicate transfections were performed for each pSPN $\alpha \mathrm{N}$ concentration, and the transfected cells then divided and grown for $6 \mathrm{hr}$ without $(A)$ or with $(B) 5 \mathrm{mM}$ HMBA. Aliquots of $10 \mu \mathrm{g}(A)$ or 5 $\mu \mathrm{g}(B)$ of RNA were analyzed with pSP $6 \alpha 132$ and pSP64 $\Delta M \alpha$ to give human $\alpha(\mathrm{H} \alpha)$ - and mouse $\alpha(\mathrm{M} \alpha)$-protected bands. $(C$ and $D \mid$ The radioactivities in human $\alpha$ RNA-protected bands were divided by those in mouse $\alpha$ RNA (Ho/M $\alpha)$, and these ratios were plotted against the concentration of $\mathrm{pSPN} \alpha \mathrm{N}$ used for electroporation. The results of this for uninduced $(C)$ and induced $(D)$ cells are shown. (E) The ratios $(\mathrm{H} \alpha / \mathrm{M} \alpha)$ in induced cells were divided by the corresponding ratios in uninduced cells to give induction ratios for each pSPN $\alpha \mathrm{N}$ concentration. $(F)$ Total plasmid molarity (pSPN $\alpha \mathrm{N}$ and pSPNKN) was calculated for each concentration of pSPN $\alpha \mathrm{N}$, and the ratio of human $\alpha$ RNA to mouse $\alpha$ RNA $(\mathrm{H} \alpha / \mathrm{M} \alpha)$ was divided by this number to give a measure of pSPN $\alpha \mathrm{N}$ expression per mole of plasmid, which was then plotted against pSPN $\alpha \mathrm{N}$ concentration for induced transfectants. (G) MELCs were transfected as for $A$ and $B$, but using pSPN $\alpha \mathrm{N} \Delta \mathrm{Eco}(5.8 \mathrm{~kb})$ and pJB8 $(5.4 \mathrm{~kb})$. Duplicate transfections were performed with 2 (lanes 1, 6), 8 (lanes 2, 7), 20 (lanes 3, 8), 50 (lanes 4, 9), and $100($ lanes 5,10$) \mu \mathrm{g} / \mathrm{ml} \mathrm{pSPN \alpha N \Delta Eco,} \mathrm{the} \mathrm{total} \mathrm{DNA} \mathrm{concentration} \mathrm{being} \mathrm{maintained} \mathrm{at} 100 \mu \mathrm{g} / \mathrm{ml} \mathrm{by}$ the inclusion of pJB8. Shown is the analysis of $5 \mu \mathrm{g}$ of RNA for the presence of human $(\mathrm{H} \alpha)$ and mouse $(\mathrm{M} \alpha) \alpha$-globin transcripts in induced transfected cells. $(H)$ The ratio $\mathrm{H} \alpha / \mathrm{M} \alpha$ in $G$ was plotted against pSPN $\alpha \mathrm{N} \Delta$ Eco concentration. 
the protected human $\alpha$ RNA bands was expressed as a ratio to mouse $\alpha$ RNA for each DNA concentration (Fig. $2 \mathrm{C}, \mathrm{D} \mid$. In both uninduced and induced cells, the amount of human $\alpha$ transcript increased linearly between 20 and $50 \mu \mathrm{g} / \mathrm{ml}$, but the system appeared to saturate above these values. However, induction is consistent throughout the range of pSPN $\alpha \mathrm{N}$ concentrations used (Fig. 2E). Thus, provided carrier DNA was present, induction was seen at $\mathrm{pSPN} \alpha \mathrm{N}$ concentrations as low as 2 $\mu \mathrm{g} / \mathrm{ml}$. At this concentration, the volume of an erythroleukemia cell would be occupied by $\sim 100$ molecules of this plasmid. Because the DNA is in solution and complete equilibration of cell contents with the external medium is an unlikely consequence of electroporation, this figure is probably an upper limit for the copy number per cell.

If induction is an effect on transcription, then saturation for $\alpha$-globin expression at similar concentrations of pSPN $\alpha \mathrm{N}$ in both uninduced and induced MELCs could imply that induction does not affect binding of a ratelimiting factor but, rather, affects its ability to activate transcription once bound. However, $\mathrm{pSPN} \alpha \mathrm{N}$ is a $9-\mathrm{kb}$ plasmid, whereas the vector with which it was cotransfected is $3 \mathrm{~kb}$. Thus, although DNA concentration was maintained at $100 \mu \mathrm{g} / \mathrm{ml}$, plasmid molarity declined as pSPN $\alpha \mathrm{N}$ made up an increasing proportion of the DNA. If the amount of $\alpha$-globin transcript in induced cells is corrected for total plasmid molarity and plotted against $\mathrm{pSPN} \alpha \mathrm{N}$ concentration (Fig. 2F), the relationship is linear. The same is true for uninduced cells (not shown). To test this relationship directly, cells were transfected with various concentrations of $\mathrm{pSPN} \alpha \mathrm{N} \Delta \mathrm{Eco}(5.8 \mathrm{~kb}$, derived from $\mathrm{pSPN} \alpha \mathrm{N}$ and behaving indistinguishably from it; see Methods), together with pJB8 (5.4 kb) so that both the total DNA concentration and plasmid molarity were approximately constant (Fig. 2G). The amount of human $\alpha$ transcript was then linearly related to pSPN $\alpha \mathrm{N} \Delta$ Eco concentration (Fig. $2 \mathrm{H}$ ), in which case expression was directly proportional to the number of copies of the transfecting gene and the total molar concentration of plasmid. Therefore, this system does not saturate for either expression or induction when up to $100 \mu \mathrm{g} / \mathrm{ml}$ of plasmid containing the $\alpha$-globin gene is used for electroporation, provided carrier DNA is present. The dependence on molarity, whether of pSPNKN or the related cosmid vector pJB8, would suggest that specific sequences in these plasmids affect either transfection or expression by binding with an inhibitor. We have excluded the possibility that plasmid sequences contribute to induction by inserting the human $\alpha$-globin gene in the NotI site of the unrelated vector pCos6EMBL (Ehrich et al. 1987; not shown). Linearization of plasmids before transfection also does not affect induction (not shown).

\section{Time course of human a-globin expression following induction}

The rapidity with which the human genes were induced following transfection and induction was surprising in view of the lag of $12-24 \mathrm{hr}$ characteristic of the response of the mouse globin genes. We therefore examined in more detail the accumulation of human transcript with time (Fig. 3). The mouse $\alpha$-globin genes responded to induction with a small increase in transcript detected by $12 \mathrm{hr}$ and an increase of 20 -fold by $24 \mathrm{hr}$. The human gene, on the other hand, gave a detectable response by 1 $\mathrm{hr}$ after induction, and the amount of $\alpha$-globin transcript increased rapidly to a maximum between 3 and $6 \mathrm{hr}$ before declining. The same decline in expression is seen following transfection of MELCs with other genes (not shown).

The useful span of this transient assay is therefore limited to the first 3-6 hr following transfection. The subsequent decline in the amount of transcript may have any of a number of causes, including cell death, destruction of plasmid, or inhibition of transcription. The stability of globin mRNA in MELCs (Volloch and Housman 1981) makes RNA degradation a less likely cause. We analyzed isolated nuclei for the presence of plasmid following transfection and found no significant decrease in the amount of plasmid (not shown) and no evidence for the entry of plasmid DNA into nucleosomes (Enver et al. 1988). However, because we did not know what fraction of the DNA associated with the nuclei was transcriptionally active, we considered that these analyses would be difficult to interpret.

\section{Dependence of expression on the presence of inducer and on protein synthesis}

The rapid response to induction of the transfecting globin genes could be due to either a stable or unstable

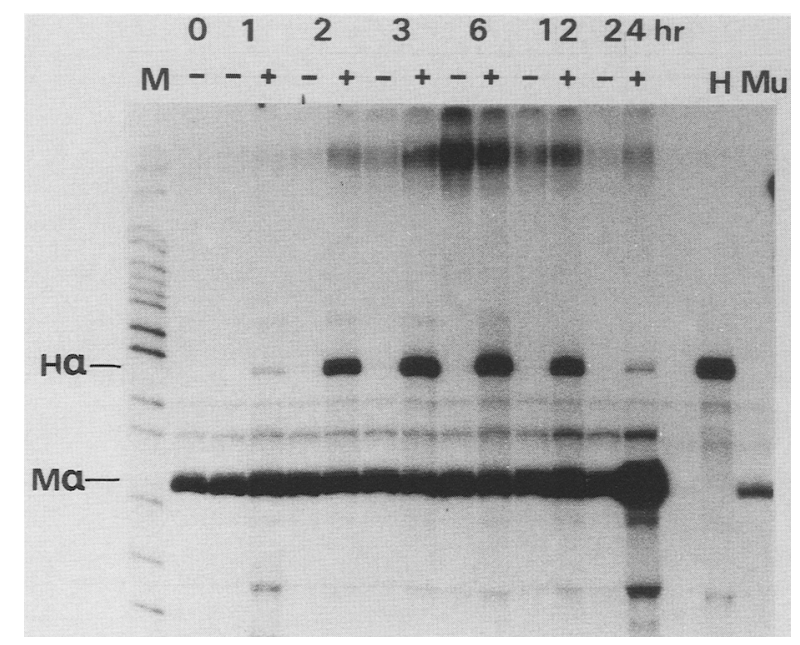

Figure 3. Expression of the human $\alpha$ gene with time following transfection. MELCs were electroporated in the presence of 10 $\mu \mathrm{g} / \mathrm{ml} \mathrm{pSPN} \alpha \mathrm{N}$ and $90 \mu \mathrm{g} / \mathrm{ml} \mathrm{pSPNKN}$. The pool of transfected cells was divided and grown with $(+)$ and without $(-15 \mathrm{~mm}$ HMBA for the times shown. Five micrograms of RNA and samples of human $(\mathrm{H})$ and mouse $(\mathrm{Mu})$ bone marrow RNA were analyzed, by use of $\mathrm{pSP} 6 \alpha 132$ and $\mathrm{pSP} 64 \Delta \mathrm{M} \alpha$, to give protected fragments representing human $(\mathrm{H} \alpha)$ and mouse $\{\mathrm{M} \alpha \mid$-globin mRNA. 
change in the cells. To distinguish between these alternatives, the effect on expression of removing inducer from induced transfected cells was examined (Fig. 4A, lanes 1-4). Two aliquots of cells transfected with pSPN $\alpha \mathrm{N}$ were grown for $2 \mathrm{hr}$ in the presence of HMBA. One was harvested (Fig. 4A, lane 2), and the other was grown for an additional $4 \mathrm{hr}$ without inducer (Fig. 4A, lane 3). Both of these cultures contained the same amount of human $\alpha$ RNA and half as much as a culture grown with inducer for the full $6 \mathrm{hr}$ (Fig. 4A, lane 4). Therefore, the induction response is reversed by removal of HMBA. The same conclusion was drawn from analogous experiments with cells transfected with the human $\beta$-globin gene. Thus, rapid induction of transient transfectants must be either a direct response to the inducer, which seems unlikely, or must involve an unstable intermediate.

When MELCs are exposed to inducer for $12 \mathrm{hr}$ or longer, stable changes in the cells allow subsequent mouse globin expression even if the inducer is removed (Gusella et al. 1976; Chen et al. 1982). Longer exposures to inducer may therefore lead to commitment to expres- sion of the transfecting genes, as well as the mouse genes. To test this, uninduced cells and cells grown with HMBA for $36 \mathrm{hr}$ were cotransfected with SPN $\alpha \mathrm{N}$ and pSPhAPRT and then grown with or without HMBA for an additional $6 \mathrm{hr}$ (Fig. 4D). The plasmid pSPhAPRT contains the hamster APRT gene, which is expressed constitutively in both transiently transfected MELCs (shown here) and in stable MELC transfectants (Chao et al. 1983). The human $\alpha$-globin gene was expressed at a similar level with respect to the APRT gene whether or not the cells had been exposed to HMBA before transfection. A similar experiment showed the same to be true of the human $\beta$-globin gene (Fig. 4D). Furthermore, irrespective of the time of exposure of the cells to inducer, sequences contained in the transfecting globin genes are not responsive to stable changes that allow the endogenous mouse genes to be expressed in the absence of inducer.

The rapid response of the human $\alpha$-globin gene to induction and its lability suggested that de novo protein synthesis might not be required. Cells were transfected with $\mathrm{pSPN} \alpha \mathrm{N}$, then divided and grown with or without

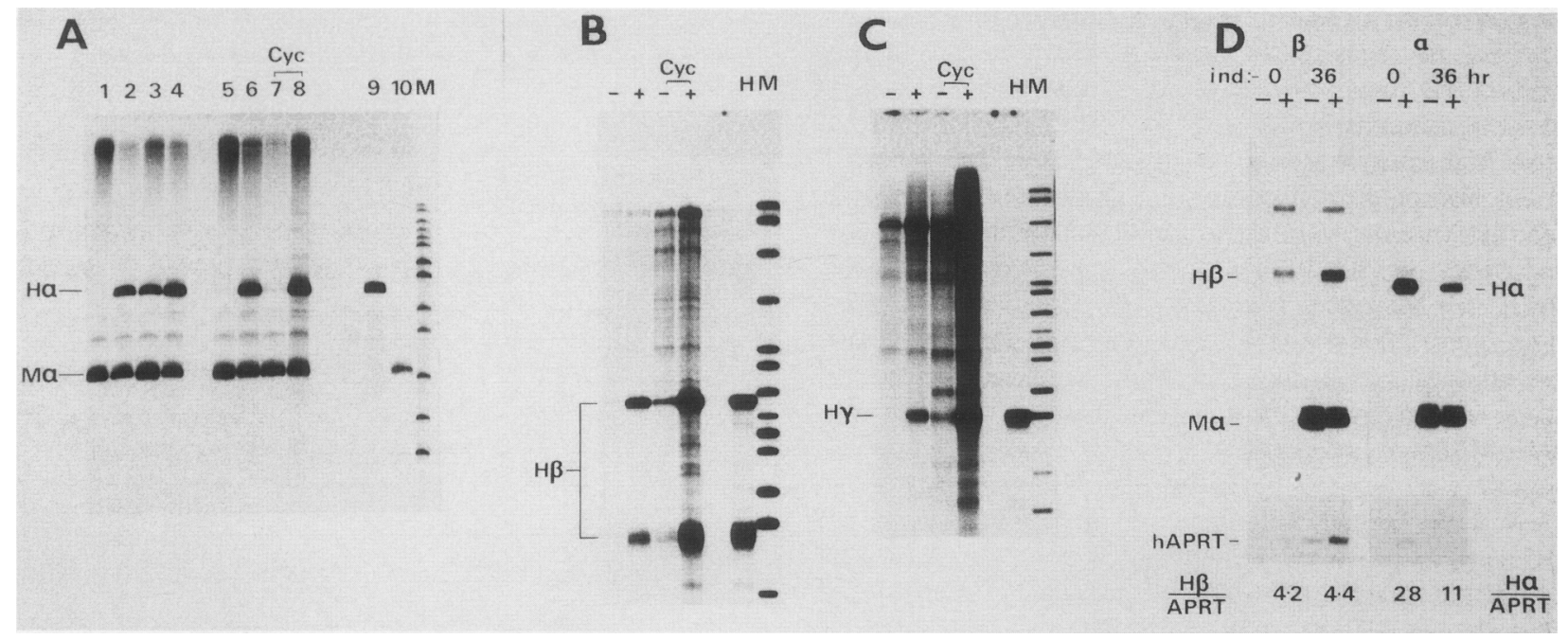

Figure 4. The dependence of induced expression of human globin genes on the presence of inducer, on protein synthesis, and on exposure of cells to HMBA prior to transfection. (A) MELCs were electroporated with $10 \mu \mathrm{g} / \mathrm{ml} \mathrm{pSPN \alpha N}$ and $90 \mu \mathrm{g} / \mathrm{ml} \mathrm{pSPNKN}$ and grown without HMBA for $6 \mathrm{hr}$ (lane 1), with $5 \mathrm{mM}$ HMBA for $2 \mathrm{hr}$ (lane 2), with $5 \mathrm{~mm} \mathrm{HMBA}$ for $2 \mathrm{hr}$ and, after harvesting, washing, and resuspension in fresh medium, for an additional $4 \mathrm{hr}$ without HMBA (lane 3) or for $6 \mathrm{hr}$ with $5 \mathrm{mM}$ HMBA (lane 4). Transfected cells were also grown without (lanes 5 and 7) or with (lanes 6 and 8$) 5 \mathrm{~mm} \mathrm{HMBA}$ and without (lanes 5 and 6 ) or with (lanes 7 and 8) 1.5 $\mu \mathrm{g} / \mathrm{ml}$ cycloheximide for $6 \mathrm{hr}$. Five micrograms of RNA and samples of human (lane 9) and mouse (lane 10) marrow RNA were hybridized to give human $(\mathrm{H} \alpha)$ - and mouse $(\mathrm{M} \alpha)$-protected fragments. $(B)$ MELCs were transfected with $100 \mu \mathrm{g} / \mathrm{ml}$ of pSPNBN and grown with $(+)$ or without $(-\mid 5 \mathrm{mM}$ HMBA and with (Cyc) or without $1.5 \mu \mathrm{g} / \mathrm{ml}$ cycloheximide for $6 \mathrm{hr}$. Twenty micrograms of RNA and an aliquot of human marrow RNA $(\mathrm{H})$ were hybridized with a human $\beta$ probe (pSP64H $\beta 142$ ), giving protected fragments representing the first and part of the second exon of human $\beta$ mRNA $(\mathrm{H} \beta) .(C)$ MELCs were transfected as in $B$, except that cells were electroporated with $100 \mu \mathrm{g} / \mathrm{ml} \mathrm{pSPN} \gamma \mathrm{N}$, and 20- $\mu \mathrm{g}$ samples of RNA and an aliquot of human marrow RNA (H) were hybridized with the human $\gamma$ probe (pSP65H $\gamma 145$ ) to give fragments protected by human $\gamma$ RNA $(\mathrm{H} \gamma)$. $(D)$ Cells grown without inducer $(0 \mathrm{hr})$ or with 5 mM HMBA for $36 \mathrm{hr}$ prior to transfection $(36 \mathrm{hr}$ ) were electroporated with $75 \mu \mathrm{g} / \mathrm{ml} \mathrm{pSPN} \beta N$ and $75 \mu \mathrm{g} / \mathrm{ml} \mathrm{pSPhAPRT}$ ( $\beta$ ) or with 10 $\mu \mathrm{g} / \mathrm{ml} \mathrm{pSPN \alpha N}, 75 \mu \mathrm{g} / \mathrm{ml} \mathrm{pSPhAPRT}$, and $65 \mu \mathrm{g} / \mathrm{ml}$ pSPNKN $(\alpha)$. The cells were then grown for an additional $6 \mathrm{hr}$ with $/+\mid$ or without (-) 5 mM HMBA. Ten-microgram samples of RNA were analyzed for the presence of human $\beta$ mRNA (H $\beta$ ), and 5- $\mu$ g RNA samples were analyzed for human $\alpha$ RNA $(\mathrm{H} \alpha)$ with $\mathrm{pSP} 64 \mathrm{H} \beta 135$, which protects most of the first exon of $\beta$ mRNA, and pSP64 $\alpha 132$, respectively. Aliquots of $0.25 \mu \mathrm{g}$ RNA were analyzed for the presence of mouse $\alpha$-globin mRNA (M $\alpha$ ) with pSP64 $\Delta \mathrm{M} \alpha$, and 15- $\mu \mathrm{g}$ aliquots were analyzed for hamster APRT transcripts (hAPRT). To correct for variation in transfection efficiency, radioactivities in human globin-protected fragments were divided by those in hAPRT. These ratios, for transfected cells grown with inducer, are shown below. 
cycloheximide for 15 min before HMBA was added (Fig. 4A, lanes 5-8). Cycloheximide did not abolish induction, which therefore does not require protein synthesis. The human $\beta$ - and $\gamma$-globin genes also induced in the presence of cycloheximide (Fig. 4B,C). If proteins mediate this induction response, they must do so by being reversibly modified.

\section{Specificity of induction}

To explore the responsiveness of genes other than the human globin genes, and to identify sequences that confer inducibility, we used constructs in which the chloramphenicol acetyltransferase (CAT) gene is driven by various viral promoters, or by the $\alpha$ - or $\beta$-globin promoters (Fig. 5). pMMTVcat contains the mouse mammary tumor virus long terminal repeat (LTR) (J. Devine, unpubl.), and pSrM2cat contains the Moloney murine sarcoma virus LTR (Laimins et al. 1982). pRSVcat contains the Rous sarcoma virus LTR (Gorman et al. 1982a), pSV2cat contains the early promoter from SV40 (Gorman et al. 1982b), and pAT153cat contains no eukaryotic promoter. MELCs were transfected with each of these constructs, and one of three such experiments, all giving similar results, is shown (Fig. 5A). None of these virally promoted CAT genes gave significant increases in expression on induction, though in subsequent experiments, we detected a small and reproducible response by pRSVcat. The largest of any increase was seen when cells transfected with pMMTVcat, which contains a glucocorticoid responsive element (Lee et al. 1981), were exposed to dexamethasone.

Constructs in which the $\alpha$ - and $\beta$-globin promoter regions replaced the early SV40 promoter in pSV2cat gave inducible but weak responses in similar experiments. Higher levels of expression were consistently obtained when the plasmid vector sequence was replaced by pUC13 (see Methods). pUC $\alpha$ cat, pUC $\beta$ cat, and

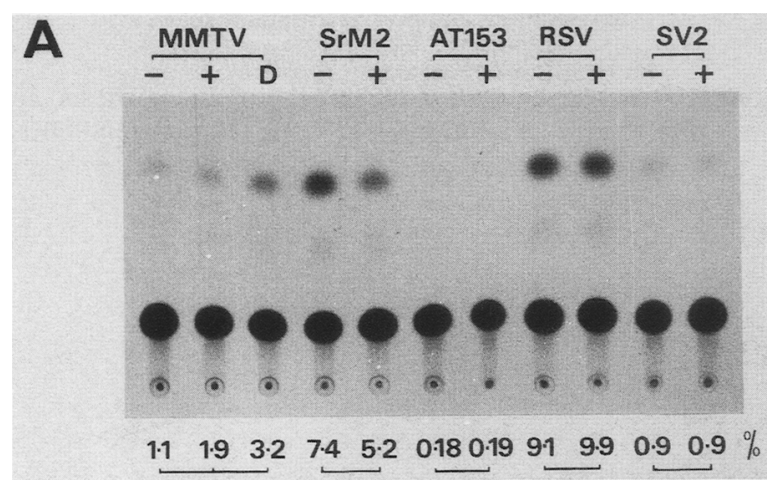

pUCSV2cat contain the $\alpha$ - and $\beta$-globin, and early SV40 promoters. pUCcat contains no eukaryotic promoter. pIRV, which contains a $\beta$-galactosidase gene driven by the rat $\beta$-actin promoter (constructed by I. Morgenstern and H. Land, ICRF, London), was cotransfected with each construct (Fig. 5B). Both pUCacat and pUCßcat were inducible, whereas pUCSV2cat was expressed constitutively. However, pIRV also responded to induction with a 5- to 10 -fold increase in $\beta$-galactosidase activity. Thus, on the one hand, the APRT gene (Fig. 4D) and a number of viral promoters do not respond to induction, and on the other hand, $\alpha-, \beta$-, and $\gamma$-(not shown) globin and rat $\beta$-actin promoters do. We show below that the herpes simplex virus-1 (HSV-1) thymidine kinase (TK) gene promoter is also inducible. These results demonstrate that the induction response is not globin specific.

\section{Cis-acting sequences responsible for induction}

To define further the cis-acting sequences responsible for induction, a series of deletions were made in pUCacat by use of exonuclease III, and for deletions close to the CAAT box, a series of oligonucleotides were used to give deletions extending down to and through the CAAT box. The response of these constructs following transfection and induction was measured by both CAT and RNA analyses (not shown). Deletion of sequences from -1375 to -76 relative to the cap site gave a decrease in the level of expression similar to that described previously (Whitelaw et al. 1989), but induction remained unaffected. Removal of an additional $8 \mathrm{bp} 3^{\prime}$ to position -76 destroyed the CAAT box and caused the loss of measurable expression. Induction must therefore be mediated by sequences between an intact CAAT box and the translation initiation codon.

To eliminate the possibility that sequences between the $\alpha$-globin cap site and the initiation codon are responsible for induction, a universal leader sequence (uls), de-

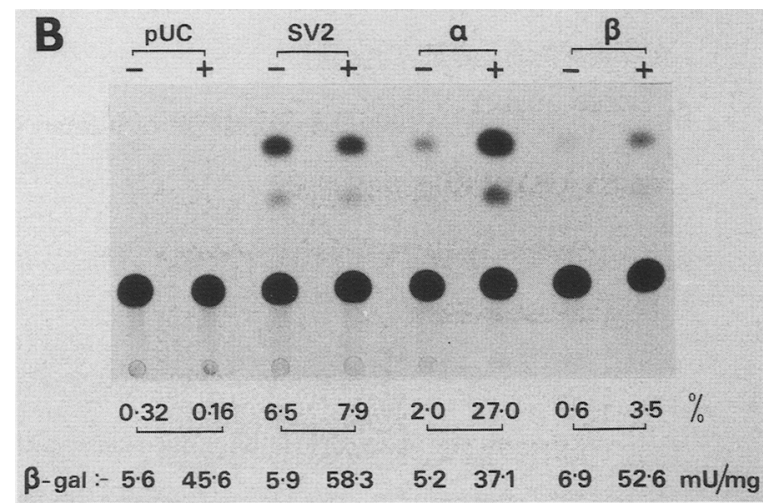

Figure 5. Expression of virally promoted and $\alpha$ - and $\beta$-globin-promoted CAT genes. (A) MELCs were transfected with $100 \mu \mathrm{g} / \mathrm{ml}$ pMMTVcat (MMTV), pSrM2cat (SrM2), pAT153cat (AT153), pRSVcat (RSV), and pSV2cat (SV2). Transfected cells were grown for 12 hr, with $(+\mid$ and without $|-| 5 \mathrm{mM}$ HMBA and, in one case, with $2 \mu \mathrm{M}$ dexamethasone (D). Shown below is the percent conversion of $\left[{ }^{14} \mathrm{C}\right.$ |chloramphenicol to its major acetylated derivative per milligram of protein $(\%)$. (B) MELCs were transfected with $75 \mu \mathrm{g} / \mathrm{ml}$ of pIRV and $75 \mu \mathrm{g} / \mathrm{ml}$ of each of the following: pUCcat (pUC); pUCSV2cat (SV2); pUC $\alpha$ cat $(\alpha)$; pUC $\beta$ cat $(\beta)$. Transfected cells were grown with $(+)$ or without $(-) 5 \mathrm{~mm}$ HMBA for $12 \mathrm{hr}$. Shown below is the percent conversion of $\left[{ }^{14} \mathrm{C}\right] \mathrm{chloramphenicol}$ per milligram of protein $(\%)$ and $\beta$-galactosidase activity in milliunits per milligram $(\mathrm{mU} / \mathrm{mg})$ of protein. 
signed to be linked to a number of inducible promoters, was inserted into pUCSV2cat. Into this construct the minimal promoter elements of the $\alpha$ - and $\beta$-globin genes and the HSV-1 TK promoter were inserted (Fig. 6). These constructs preserve the normal spacing between the TATA box and a potential new cap site. Expression of these constructs was less than that of those containing the normal cap site and leader sequences, and this prevented the use of RNase protection analysis.

When transfections were performed in the absence of pIRV (Fig. 6A), the promoterless CAT control (pUCcat) gave low uninducible levels of CAT activity, whereas pUCSV2cat was expressed at a higher constitutive level (Fig. 6A). These relative levels of expression were seen consistently. pUCaulscat $\Delta-76$ lacks the normal cap site and leader sequence present in pUC $\alpha$ cat $\Delta-76$ but still shows induction. However, its level of expression is reduced, probably as a result of changes to the normal sequence around the cap site (Smale and Baltimore 1989). pUC $\beta$ ulscat $\Delta-79$ is also inducible, but again its expression is much reduced compared with pUC $\beta$ cat $\Delta-$ 371 , which contains both the normal cap site and leader sequence and more sequence $5^{\prime}$ to the CAAT box. pUCTKulscat was also induced. Thus, inducibility is conferred by sequences lying between or including the CAAT and TATA boxes of the $\alpha$ - and $\beta$-globin genes and upstream from the cap site of the HSV-1 TK gene.

Cotransfection of these constructs with pIRV affected induction (Fig. 6B). pIRV, itself, gave an induction ratio of $\sim 10$-fold in all transfections. The more strongly expressed constructs, pUC $\alpha$ cat $\Delta-76$ and pUC $\beta$ cat $\Delta-371$, remained inducible in the presence of pIRV, though less so than in its absence. The ulscat constructs, pUCaulscat $\Delta-76$, pUC $\beta$ ulscat $\Delta-79$, and pUCTKulscat, were then all constitutive, and the promoterless control construct, pUCcat, was inhibited on induction. This is pre-

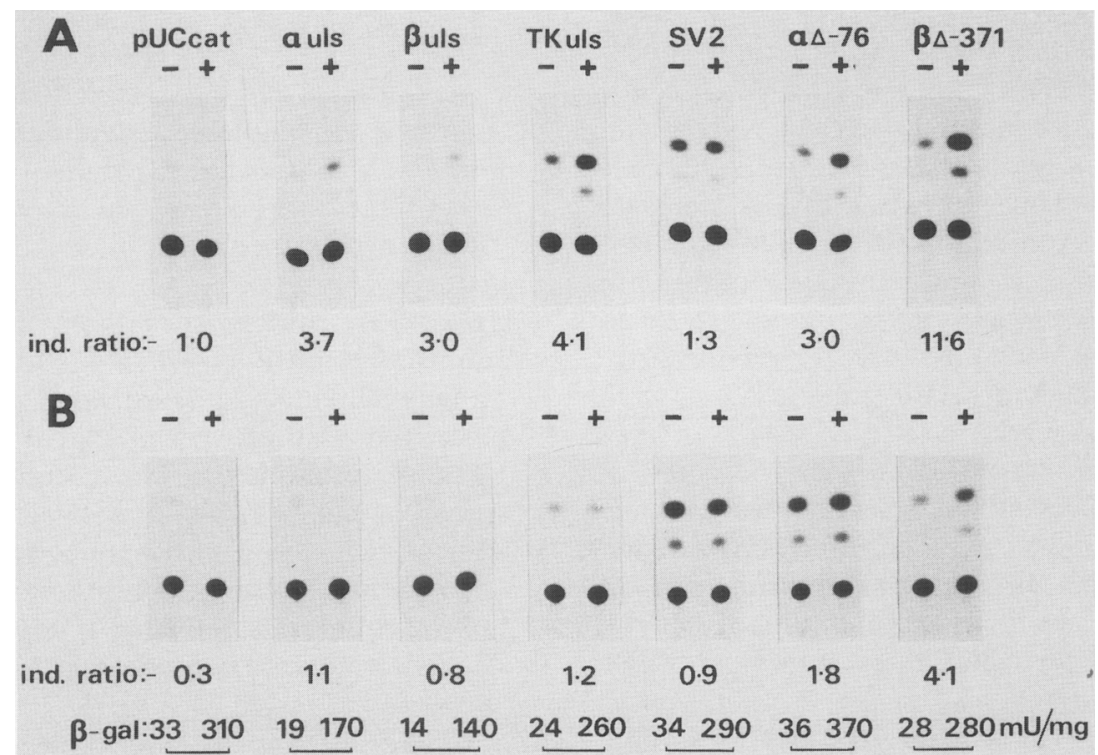

human alpha-alobin ULS CAT

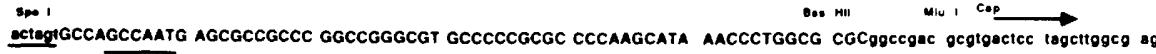

human bete-globln ULS CAT

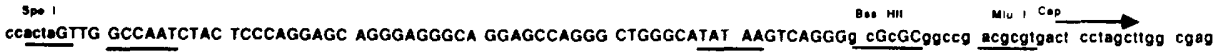

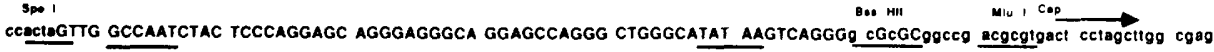

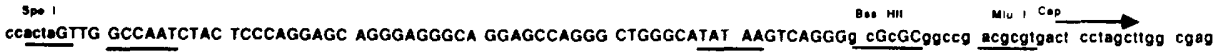

HSV-1 TK ULS CAT

Xho 1

Che I

ECo A1

$\underset{\text { TGACGCGCgg cegacgcglg actectagct }}{\longrightarrow}$

Figure 6. Expression of constructs containing minimal promoter regions and a common cap site and leader sequence. $(A)$ MELCs

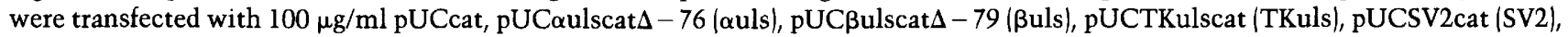
pUC $\alpha$ cat $\Delta-76(\alpha \Delta-76)$, or pUC $\beta$ cat $\Delta-371(\beta \Delta-371)$, and the transfected cells were grown with $(+)$ or without $(-15 \mathrm{~mm}$ HMBA for

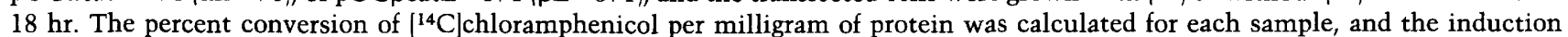
ratios for each transfection are shown below (ind. ratio). $(B)$ MELCs were transfected as in $A$, except that $50 \mu \mathrm{g} / \mathrm{ml}$ of pIRV was included in each transfection. Shown below are the induction ratios for CAT activity and $\beta$-galactosidase activity in milliunits per milligram $(\mathrm{mU} / \mathrm{mg})$ of protein. Also shown are the sequences of the promoter regions of the uls CAT constructs. CAAT and TATA boxes and some restriction sites are underlined. Nucleotides corresponding to those in the intact genes are in uppercase letters. 
sumably due to competition imposed by the presence of pIRV, the effect being greatest on the most weakly expressed constructs.

\section{Cell specificity of the induction response}

This induction response is not specific for globin genes, and to determine its cellular specificity, MELCs, K562, a human erythroid cell line, and NSO, a mouse myeloma line, were transfected with pUC $\alpha$ cat $\Delta-603$ and grown with or without $5 \mathrm{~mm}$ HMBA or $1.4 \%$ dimethyl sulfoxide (DMSO). All three cell types showed a 10-fold induction of CAT with either inducer (not shown). Thus, the mechanism of induction is not cell-type specific.

Although the $\alpha$-and $\beta$-globin genes were both induced in transiently transfected MELCs, expression of the $\alpha$ globin gene was much greater than that of the $\beta$-globin gene, a situation similar to that in nonerythroid cells (Banerii et al. 1981; Mellon et al. 1981; Humphries et al. 1982; Treisman et al. 1983; Whitelaw et al. 1989). This suggested that the transiently transfecting globin genes gained no advantage from being expressed in an erythroid environment. Their expression was therefore compared with that of a construct containing a well-defined tissue-specific promoter and enhancer. $\operatorname{Ig} \beta$ consists of an immunoglobulin gene promoter fused to the body of the human $\beta$-globin gene and including the $\mathrm{IgH}$ enhancer downstream (see Methods; K. Weston, unpubl.). This construct would be expected to express well in a myeloma cell line and poorly in MELCs (Banerii et al. 1983; Grosschedl and Baltimore 1985; Picard and Schaffner 1985). MELCs and NSO cells were cotransfected with the $\alpha$-globin gene and either the $\beta$-globin gene or Ig $\beta$ (Fig. 7). To enable comparison of $\beta$-globin gene expression with that of the other constructs, five times as much pSPN $\beta N$ was used for transfection and five times as much RNA was analyzed so that the $\beta$ globin signal was multiplied 25 times relative to those of the $\alpha$-globin and $\operatorname{Ig} \beta$ genes. The $\alpha$ - and $\beta$-globin genes were induced in both cell lines and expressed at similar levels relative to each other, implying that the expression of the $\beta$-globin gene, like that of the $\alpha$-globin gene, shows little regard for cell type in a transient expression system. This contrasts with the behavior of the $\operatorname{Ig} \beta$ gene in the same system. Its transcripts are undetectable in MELCs, compared with the $\alpha$-globin gene, but it is expressed at a relatively high and nearly constitutive level in the myeloma cell line NSO, making its behavior comparable to that of strongly expressed virally promoted CAT constructs in MELCs (Fig. 5). The 5-kb BglII fragment containing the human $\beta$-globin gene that has been used in these experiments includes sequences implicated in tissue-specific expression in MELCs and transgenic mice (Charnay et al. 1984; Wright et al. 1984; Townes et al. 1985; Behringer et al. 1987; Kollias et al. 1987; Antoniou et al. 1988). These regulatory elements do not appear to confer on the $\beta$-globin gene the highlevel tissue-specific expression conferred by immunoglobulin regulatory sequences.

The observation of induction in transiently trans-

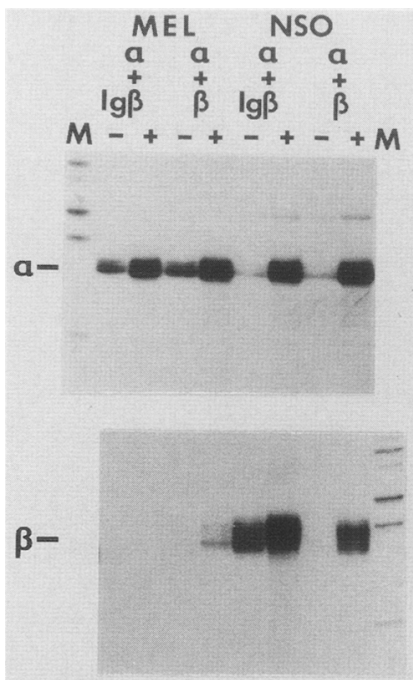

Figure 7. Comparison of the induced expression of the $\alpha$ - and $\beta$-globin genes and of $\operatorname{Ig} \beta$ in MELC and a mouse myeloma cell line NSO. MELCs (MEL) or NSO cells were cotransfected with $10 \mu \mathrm{g} / \mathrm{ml} \mathrm{pSPN} \alpha \mathrm{N}$ and either $50 \mu \mathrm{g} / \mathrm{ml} \mathrm{pSPN} \beta N$ or $10 \mu \mathrm{g} / \mathrm{ml}$ $\operatorname{Ig} \beta$ (see Methods), the total DNA concentration being made to $100 \mu \mathrm{g} / \mathrm{ml}$ with pSPNKN. The transfected cells were then grown for $6 \mathrm{hr}$ with $(+)$ or without $(-) 5 \mathrm{~mm}$ HMBA. $2.5 \mu \mathrm{g} / \alpha$, $\operatorname{Ig} \beta)$ or $12.5 \mu \mathrm{g}(\beta)$ of RNA were analyzed.

fected K562 cells suggested that the endogenous globin genes might also respond. K562 cells were therefore grown with hemin, an inducer of K562 (Rutherford et al. 1981), with HMBA, or with both inducers (Fig. 8). As expected, hemin induced both the $\alpha$-globin and the embryonic $\zeta$-globin genes. However, HMBA caused a dramatic reduction in the amount of both transcripts, irrespective of the presence or absence of hemin. Visual inspection of the cell pellets showed that the treated cells were virtually white compared with the yellow/orange color of untreated cells or the red of hemin-induced cells. Although growth was inhibited by HMBA, microscopy showed no evidence of extensive cell death. Therefore, as well as stimulating expression of constructs in transiently transfected K562, HMBA must also act at a regulatory step that is independent of that affected by hemin.

\section{Discussion}

We have shown that in transiently transfected MELCs, exposure to HMBA results in a rapid increase in expression of the human $\alpha-, \beta$-, and $\gamma$-globin genes and HSV-1 TK and rat $\beta$-actin-promoted constructs. Although this response is not specific for globin genes, it does not extend to strong retroviral or viral promoters or to the hamster APRT gene and thus shows some template specificity. Replacement of the normal transcribed sequences in several inducible genes does not prevent induction, making changes in RNA processing, transport, or stability unlikely as an explanation and leading us to 


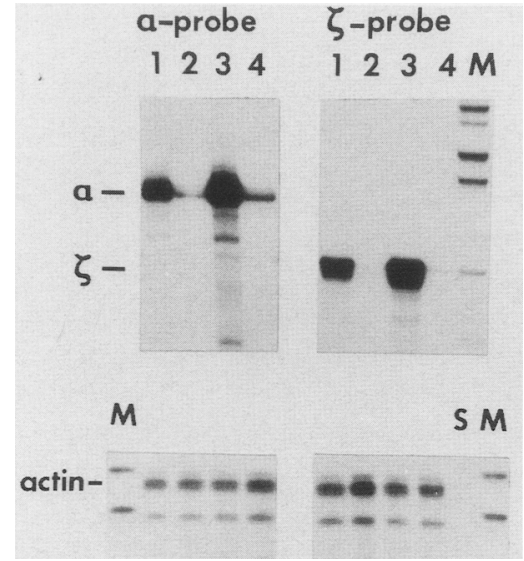

Figure 8. Expression of the endogenous $\alpha$ - and $\zeta$-globin genes in $\mathrm{K} 562$ cells following exposure to HMBA or hemin. K562 cells were grown without additions (lane 1) with $5 \mathrm{~mm}$ HMBA (lane 2) or $50 \mu \mathrm{M}$ hemin (lane 3), or with both inducers (lane 4) for 48 hr. Aliquots of $2.5 \mu \mathrm{g}$ of RNA were analyzed for the presence of $\alpha, \zeta$, and actin transcripts. The rat actin probe was also hybridized in the absence of K562 RNA (S).

conclude that induction acts at the level of transcription.

The response depends on the continued presence of inducer at both early and late times following induction. Furthermore, pre-exposure of transfected cells to cycloheximide shows that new protein synthesis is not required. These properties do not distinguish between a direct or indirect effect of inducer on transcription, but neither HMBA nor DMSO affect in vitro expression of the human $\alpha$-globin gene in a MELC extract (P.L. Campbell and R.W. Jones, unpubl.); thus, we conclude that a direct effect is unlikely. We note that in the case of the human $\beta$ - and $\gamma$-globin genes, but not the $\alpha$-globin gene, cycloheximide, by itself, causes an increase in the accumulation of RNA and a superinduction when it is combined with HMBA. This superinduction phenomenon has been observed in a number of inducible systems (Greenberg et al. 1986; Sen and Baltimore 1986).

The regions of the human $\alpha$ - and $\beta$-globin promoters bounded by the CAAT and TATA boxes (pUCaulscat $\Delta-76$ and pUC $\beta u l s c a t \Delta-79$; Fig. 6) are sufficient for induction. More recently (P.L. Campbell and R.W. Jones, unpubl., we detected induction of correctly initiated transcript from constructs lacking functional promoter sequences other than the TATA box and cap site upstream from the rabbit $\beta$-globin structural gene and the SV40 enhancer (Westin et al. 1987; Muller et al. 1988). Thus, sequences upstream from the TATA box may not be required. This possibility is strengthened by a lack of correlation between upstream sequences and inducibility. For example, the CAAT boxes of the inducible HSV-1 TK promoter and the constitutive Moloney murine sarcoma virus LTR bind the same protein (Graves et al. 1986), and the HSV-1 TK promoter also shares functional SP1 sites (McKnight et al. 1984) with the noninducible SV40 early promoter (Dynan and Tiian 1983). This supports the view that induction acts at a step intimately involved in transcription initiation and is compatible with the findings of Cowie and Myers (1988), who used DEAE-dextran to transfect MELCs transiently with constructs containing the mouse $\beta$ globin promoter. Mutations through this promoter affected expression and the extent of induction, but none abolished it.

The labile nature of the induction response and the absence of a requirement for protein synthesis suggest that it may involve secondary modification of a transcription factor, for example, by $O$-glycosylation (Jackson and Tiian 1988) or phosphorylation (Sen and Baltimore 1986; Sorger et al. 1987; Sorger and Pelham 1988; Yamamoto et al. 1988; Bagchi et al. 1989; Hiebert et al. 1989; Raychaudhuri et al. 1989). RNA polymerase, which is known to be phosphorylated (Cisek and Corden 1989; Lee and Greenleaf 1989), would be among the candidates for this role. Changes in protein kinase activity, observed as an early event in MELC differentiation (Marks and Rifkind 1989; Melloni et al. 1987), could provide the means of secondary modification, leading to increased binding of a factor intimately involved in transcript initiation. Constitutive promoters, such as those of retroviral LTRs, may differ from inducible promoters in not requiring this factor or they may not be rate-limited at the inducible step. Other early events in MELC induction, such as changes in the expression of a number of proto-oncogenes (Ramsay et al. 1986) and a cyclical change in DNA methylation (Razin et al. 1988), also do not require protein synthesis and may share a common transduction pathway with this induction response.

Although HMBA causes induction of transiently transfecting genes in MEL, K562 and NSO cells, the cellular consequences of induction differ according to the cell type. Although endogenous globin gene expression is switched on in MELCs, it is switched off in K562 cells. Loss of erythroid and monocytic markers, with a concomitant increase in expression of megakaryocytic markers, has been described following induction of K562 cells with phorbol 12-myristate 13-acetate (PMA) (Tabilio et al. 1983; Siebert and Fukuda 1985; Alitalo et al. 1988). The effect of HMBA on K562 cells may be similar to that of PMA, and we speculate that the apparatus of globin gene expression in K562 cells is unstable and that HMBA causes terminal differentiation at the expense of globin expression down a nonerythroid pathway dictated by the cell. Many transformed cell lines undergo terminal differentiation following exposure to HMBA (Marks and Rifkind 1989), and induction probably involves changes that are not specific to any one differentiation program, whereas the program itself is largely predetermined. The available evidence suggests that this may be so for globin expression in MELCs. Thus, in stably transfected cells, the DNase I-sensitive sites in the DCR show the same erythroid-specific pattern before and after induction (van Assendelft et al. 1989). Also, the erythroid-specific protein-binding patterns around the $\beta$-globin gene and the abundance of the erythroid transcription factor, GF-1, show little, if any, 
change (de Boer et al. 1988; Wall et al. 1988; Tsai et al. 1989). Furthermore, regulatory events determining whether $\gamma$ - or $\beta$-globin genes will express in MELC/ human fetal erythroid cell hybrids occur before induction (Papayannopoulou et al. 1986), showing that mechanisms for regulating globin gene expression are already in place. Consequently, globin gene expression in MELCs may be blocked at steps that are not erythroid specific.

Changes detected in transient transfectants as a nonspecific increase in the activity of the transcription apparatus could provide a positive component in the activation of cellular and stably integrated genes during MELC differentiation. If so, then one expectation would be of a correlation between the behavior of genes in transient and stable MELC transfectants. In stably transfected MELCs, the $\beta$ - and $\gamma$-globin genes and the HSV-1 TK promoter have all been observed to induce, whereas the APRT gene is expressed constitutively (Chao et al. 1983; Wright et al. 1983; Charnay and Henry 1986). These observations correlate with the behavior of these genes in transiently transfected MELCs. On the other hand, constitutive expression of the human $\alpha$ globin gene in stable transfectants (Charnay et al. 1984) appears to be at odds with its induction in transients. However, constitutive expression only implies that the rate-limiting step is constitutive and does not exclude the presence of an inducible step that may be rate-limiting in other circumstances, for example, in transient transfectants or when the gene is linked to a DCR. The variability in the induction response seen with stably integrated genes (Wright et al. 1983, 1984; Charnay et al. 1984) appears to be a function of the integration site, an effect that is abolished when the gene is linked to the $\beta$-globin DCR (van Assendelft et al. 1989). The effects on induction of both integration sites and globin local regulatory sequences (Antoniou et al. 1988) may be due to their binding of inducible factors, but these sequences may also determine whether or not a single inducible step acting elsewhere is rate-limiting and therefore measured.

Induction of stable transfecting genes and the mouse globin genes is delayed for 12-24 hr following exposure to inducer (Salditt-Georgieff et al. 1984; Sheffery et al. 1984). This delay indicates that the early stimulation of transcription seen in transient transfectants is not sufficient to cause increased expression of chromosomally integrated genes. This could be due to a requirement for de novo synthesis of transcription factors. Alternatively, the delay may be a function of chromosomal integration. For example, evidence exists that access of protein factors to DNA is inhibited by incorporation of DNA into chromatin (Emerson and Felsenfeld 1984; Workman and Roeder 1987; Workman et al. 1988; Cheng and Kelly 1989 , and this would not apply to naked DNA introduced into the cell by transient transfection. Thus, proteins modified by induction may depend for access on cell-cycle events (Conkie et al. 1981), replication (Enver et al. 1988), or changes in DNA methylation (Razin et al. 1988).
A property of endogenous mouse globin gene induction is that it shows eventual commitment or inducer independence (Gusella et al. 1976; Chen et al. 1982). No data are available to determine whether the same is true of stably integrated inducible genes, but the transient response does not show this property. Thus, other events in the terminal differentiation process would be required to explain commitment.

The rapid induction response that we have described is of interest from several points of view. We provide evidence that the activity of a ubiquitous component of the cellular transcription apparatus is regulated by secondary modification. It is likely that its abnormal regulation by HMBA or DMSO has a normal counterpart that has a role in cellular regulation of transcription. Loss of this normal control may be related to the transformed phenotype and may contribute to the block on terminal differentiation. Thus, elucidation of this process may contribute to an understanding of the transformed cell phenotype, the requirements of the terminal differentiation process, and, in the case of MELCs, globin gene expression. To do this, we are attempting to identify the factor modified by induction by using an in vitro transcription system.

\section{Methods \\ Cell culture}

MELCs 707 B10/1 were grown in suspension in RPMI 1640 medium (GIBCO), supplemented with $10 \%$ fetal calf serum, glutamine $(2 \mathrm{mM})$, penicillin $(50 \mathrm{U} / \mathrm{ml})$, and streptomycin $(50 \mu \mathrm{g} / \mathrm{ml})$. To induce differentiation, HMBA (Sigma) was added to the medium at a final concentration of $5 \mathrm{~mm}$. Alternatively, $1.4 \%$ DMSO was used. Cycloheximide was used at a concentration of $1.5 \mu \mathrm{g} / \mathrm{ml}$, sufficient to inhibit protein synthesis in MELCs by $>95 \%$ (Kaneda et al. 1985), and dexamethasone at $2 \mu \mathrm{M}$. A nonsecretory mouse myeloma cell line (NSO) and the human erythroid cell line (K562) were grown under the same conditions as MELCs.

\section{Transfection}

MELCs were transfected by electroporation (Boggs et al. 1986; Chu et al. 1987). Cells were grown to a density of between $0.5 \times 10^{6}$ and $1.0 \times 10^{6} / \mathrm{ml}$. They were harvested, washed once with PBS, and resuspended in $1 \mathrm{ml}$ of PBS containing, usually, $100 \mu \mathrm{g}$ of supercoiled plasmid DNA. The cell suspension was put into a 4-ml capacity plastic cuvette, into which were inserted two flat electrodes facing each other, $8 \mathrm{~mm}$ apart. A 1000 $\mu \mathrm{F}$ capacitor array, charged at 425 volts from an LKB 2197 power supply, was discharged through the cells. After electroporation, the cells were resuspended in medium and aliquots were distributed between flasks to which any additions had already been made. The whole procedure was conducted at room temperature. NSO and K562 cells were electroporated in the same way, except that 400 volts was used.

Where necessary, a constitutively expressed plasmid (pSPhAPRT) was included as a control for transfection efficiency. Alternatively, variation in transfection efficiency was allowed for by duplication of the transfection. Transfection efficiency for one batch of cells generally varied within a two- to threefold range. Cells $\left(4 \times 10^{7}\right)$ transfected and grown for 
various times provided between 50 and $100 \mu \mathrm{g}$ of total RNA, and multiples of this number of cells were electroporated to provide sufficient transfected cells for the number of experimental conditions.

\section{Constructs used for transfection}

The polylinker sequence of pSP65 was altered by use of standard methods to give the following sequence of restriction sites: EcoRI, SacI, SpeI, SacII, SfiI, NotI, BamHI, KpnI, BamHI, XhoI, NotI, PstI, and HindIII. Genomic DNA fragments containing globin genes were inserted into this vector (pSPNKN) in the same orientation, the $5^{\prime}$ end of the gene being nearest the EcoRI site. A 6.0-kb BgIII-XhoI fragment containing the human $\alpha_{1}$-globin gene from c $\alpha 3^{\prime} \mathrm{Bg}$ (Nicholls et al. 1987) was inserted between the BamHI and Xhol sites of pSPNKN to give pSPN $\alpha$ N. Deletion between the EcoRI and XhoI sites $3^{\prime}$ to the $\alpha$ gene in $\mathrm{pSPN} \alpha \mathrm{N}$ gave $\mathrm{pSPN \alpha N} \Delta \mathrm{Eco}$. Insertion of a $5-\mathrm{kb}$ Bglll fragment containing the human $\beta$-globin gene into the BamHI site of pSPNKN gave pSPN $\beta N$. pSPNA $\gamma N$ was made by insertion of the $3.3-\mathrm{kb}$ HindIII fragment containing the human ${ }^{\mathrm{A}} \gamma$ gene into the BamHI site of pSPNKN. pSPhAPRT was made by transfer of the hamster APRT gene in a 7.8-kb HindIII fragment (Lowy et al. 1980) into the HindIII site of pSPNKN.

$\operatorname{Ig} \beta$ is pV473ßGTIg3 [a gift from $\mathrm{K}$. Weston (unpubl.)]. It consists of the mouse $V_{H}$ promoter from pSV-V $\mu$ l (Neuberger 1983) fused to the human $\beta$-globin structural gene with the $\operatorname{IgH}$ enhancer inserted $3^{\prime}$.

\section{Globin-promoted CAT constructs}

pUCacat and pUCßcat were made as follows. The NcoI sites in pSPN $\alpha \mathrm{N}$ and pSPN $\beta N$ were cut and made flush using mung bean nuclease, and a HindIII linker was inserted. EcoRI-HindIII fragments containing the respective promoter regions were inserted between the AccI and HindIII site of pSV2cat (Gorman et al. 1982a) after the EcoRI and $A c c I$ ends had been filled by use of Klenow DNA polymerase. The SacI-BamHI fragments containing a globin promoter contiguous with the CAT structural gene were transferred to the same sites in the pUC13 polylinker to give pUC $\alpha$ cat and pUC $\beta$ cat. pUCSV2cat was made by cutting of pSV2cat (Gorman et al. 1982b/ with AccI, filling of the ends with Klenow DNA polymerase, and transfer of an AccIHindII fragment between a filled SpeI and a HindIII site of pUC $\alpha$ cat, which thereby replaced the $\alpha$-globin promoter with the SV40 early promoter. pUC $\beta$ cat $\Delta-371$ was made by deletion between the NotI site $5^{\prime}$ to the promoter region in pUCßcat and an $A c c$ site at position -371 .

\section{$5^{\prime}$ Deletion of the a-globin promoter region}

pUC $\alpha$ cat $\Delta-603$ was made by deletion between the SpeI site of the $5^{\prime}$ polylinker and a SpeI site at -603 in pUCacat. Exonuclease deletions were made by use of the SpeI and SacI sites 5' to the promoter of pUCacat $\Delta-603$ (Hoheisel and Pohl 1986).

Oligonucleotide-constructed $\alpha$-globin promoter deletions were also made. Single-stranded oligonucleotides corresponding to the antisense strand of the $\alpha$-globin promoter extended from the EagI site at -56 from the cap site to positions at and between -68 and -112 from the cap site. The $3^{\prime}$ ends of these were abutted to a SpeI site and extended an additional 6 bp to form a terminal 18-bp palindrome. These oligonucleotides were made double-stranded by mutually primed synthesis (Hill et al. 1986), the products were digested with SpeI and EagI, and these fragments were inserted between the SpeI and EagI sites of pUC $\alpha$ cat $\Delta-603$ to give pUC $\alpha$ cat $\Delta-68$ to $\Delta-112$ inclusive.
Constructs with a common cap site and leader sequence

A 31-mer oligonucleotide, 5'-CTAGAGGGCGCGCGGCCGACGCGTGACTCCT-3', was annealed with a complementary 27 -mer to give a double-stranded oligonucleotide with a blunt $3^{\prime}$ end and a SpeI complementary 5' overhang. It also contained BssHII, EagI, and MluI sites to enable different promoters to be inserted, preserving the distance between the TATA box and the new potential cap site. The HindIII site in the pUC13 polylinker $3^{\prime}$ to the CAT gene in pUC $\alpha$ cat $\Delta-76$ was cut, filled in using Klenow polymerase, and religated. The resulting plasmid was cut at the HindIII site at the junction of the $\alpha$ promoter and the CAT gene, the ends were filled, and the plasmid was cut with BssHII. The double-stranded oligonucleotide (above) was cut with BssHII, and the resulting BssHII/blunt fragment was inserted between the BssHII/blunt HindIII sites of pUCacat $\Delta-76$ to give pUC $\alpha$ ulscat $\Delta-76$.

A double-stranded oligonucleotide, spanning the CAAT and TATA boxes of the $\beta$-globin promoter, was made: 5' - CCACTAGTTGGCCAATCTACTCCCAGGAGCAGGGAGGGCAGGAGCCAGGGC TGGGCATATAAG TCAGGGGCGCGCCA-3'. This was cut with SpeI and BssHII, and the resulting fragment was inserted between the equivalent sites in pUC $\alpha$ ulscat $\Delta-76$ to give pUC $\beta$ ulscat $\Delta-79$.

pUCTKulscat was made by insertion of the promoter region of the HSV-1 TK gene into pUCaulscat $\Delta-76$. A 2-kb XhoI-linkered PvuII fragment containing the HSV-1 TK gene (McKnight 1980) was made blunt-ended, by use of Klenow DNA polymerase, and cut with MluI. The 190-bp MluI/blunt fragment containing the HSV-1 TK promoter region was inserted between the SpeI site (filled) and the BssHII site of pUCaulscat $\Delta-76$ to give pUCTKulscat.

\section{Plasmid growth and preparation}

All plasmids were propagated by transformation of Escherichia coli RRI. Plasmid DNA was prepared by alkaline SDS lysis and purified by $\mathrm{CsCl}$ equilibrium centrifugation (Maniatis et al. 1982).

\section{RNA preparation}

A composite of existing methods was used (Auffray and Rougeon 1980; Maniatis et al. 1982). MELCs were harvested, washed once with PBS, and homogenized in $10 \mathrm{ml}$ of $6 \mathrm{M}$ urea, 3 $\mathrm{M} \mathrm{LiCl}$ for $1 \mathrm{~min}$. After standing at $4^{\circ} \mathrm{C}$ overnight, the RNA was pelleted at $10,000 \mathrm{rpm}$ in a Sorvall SS34 rotor. The pellet was dissolved in $0.5 \mathrm{ml}$ of $6 \mathrm{M}$ guanidinium thiocyanate, $10 \mathrm{mM}$ Tris (pH 7.4), $0.5 \%$ Sarkosyl, $200 \mathrm{mg}$ of $\mathrm{CsCl}$ dissolved in this solution, and $0.5 \mathrm{ml}$ layered on $0.5 \mathrm{ml}$ of $\mathrm{CsCl}, 1.7 \mathrm{~g} / \mathrm{ml}$, in $10 \mathrm{mM}$ Tris ( $\mathrm{pH} 7.4$ ), and $10 \mathrm{~mm}$ EDTA. After centrifugation at 85,000 $\mathrm{rpm}$ in the Beckman TLA 100.2 rotor for $4.5 \mathrm{hr}$ at $20^{\circ} \mathrm{C}$, the supernatant was removed and the RNA was dissolved in $0.4 \mathrm{ml}$ of $10 \mathrm{mM}$ Tris (pH 7.4), $10 \mathrm{~mm}$ EDTA, and $0.1 \%$ SDS. The RNA was ethanol-precipitated and redissolved in $80 \%$ formamide hybridization buffer. The RNA was quantitated by measurement of the $E_{260}$ of a diluted aliquot.

\section{RNA analysis}

RNA was analyzed by RNase protection with the SP6 system (Melton et al. 1984). RNA recovery was monitored either by observation of cross-hybridization of the human probe to mouse sequences or by inclusion of a probe to cell RNA. Uniformly labeled RNA probes were made by use of $\left[\alpha^{-32}\right.$ P $]$ GTP (>400 Ci/mmole, Amersham). RNA-RNA hybridization, with 
$5 \times 10^{5} \mathrm{cpm}$ of radiolabeled probe and $0.25-20 \mu \mathrm{g}$ of total cellular RNA, was performed at $50^{\circ} \mathrm{C}$ for $18 \mathrm{hr}$. RNase digestion was carried out at $21^{\circ} \mathrm{C}$ for $30 \mathrm{~min}$. The protected RNA fragments were run on a denaturing $8 \%$ or $12 \%$ polyacrylamide gel. End-labeled HpaII-cut pBR322 was used as molecular weight marker. Fuji RX medical X-ray film was exposed to the dried gels at $-70^{\circ} \mathrm{C}$ with an intensifying screen. Quantitation was done by cutting out the radioactive bands, together with appropriate backgrounds, and the radioactivity was measured by scintillation counting with an LKB-Wallac Beta-plate counter.

\section{SP6 probes}

The 5' human $\alpha$ probe pSP6 132 (Charnay et al. 1984) and the $5^{\prime}$ mouse $\alpha$ probe pSP64M (Baron and Maniatis 1986) were gifts from Tom Maniatis. We used a derivative of pSP64M $\alpha$ (pSP64 $\Delta \mathrm{M \alpha}$ ), made by deletion between a Ball site in the first exon and a mung bean nuclease-treated EcoRI site in the polylinker sequence. This is protected by a 91 -bp fragment from mouse $\alpha$-globin mRNA. Two $5^{\prime}$ human $\beta$ probes were used. One a 555-bp BamHI-Ball fragment extending from +476 to -79 of the $\beta$-globin gene and cloned into pSP64 (pSP64H 3142 ; Kulozik et al. 1988), is protected by 142- and 210-bp fragments of the first and second exons of $\beta$ mRNA. The other, a gift from Bernie Morley, is a 226-bp BstNI fragment protected by $135 \mathrm{bp}$ of the first exon of the human $\beta$ gene (pSP64H $\beta 135)$. The $5^{\prime}$ human Ay probe is a 1502-bp BstEII-HindIII DNA fragment from +159 to -1343 of the human ${ }^{A} \gamma$ globin gene cloned in pSP65, giving a 145-bp protected fragment representing the first exon of the Ay gene (pSP65H $\gamma 145$ ). The human $\zeta$ probe contains a 662-bp EcoRI-BgIII fragment, overlapping the $5^{\prime}$ end of the $\zeta$-globin gene and inserted in pSP64, to give a 110-bp protected fragment. The 5' hamster APRT probe contains a 862 -bp HindII-BamHI fragment overlapping the 5' end of the hamster APRT gene (Lowy et al. 1980) inserted between the HindII and BamHI sites of pSP64 (pSP64APRT). The actin probe contains a 276-bp Aval-HindIII fragment inserted in pAM19, which protected the 76-nucleotide first exon of the rat $\beta$-actin transcript (Nudel et al. 1983). Cross-hybridization of this probe to human RNA was used as a control for RNA recovery. The 5' cat $\alpha$ probe was made by inserting the $S p e I-P v u I I$ fragment of pUCocat $\Delta-112$ between the $X b a I$ and HindII sites of pSP64 (pSP64acat).

\section{CAT assay}

MELCs transfected with constructs containing the CAT gene were grown for $8-20 \mathrm{hr}$, harvested, and washed once with PBS. The cells were resuspended in $200 \mu \mathrm{l}$ of $0.25 \mathrm{M}$ Tris ( $\mathrm{pH} 7.4$ ) and subjected to three cycles of freezing and thawing. Cell debris was removed by centrifugation, and aliquots of the supernatant, containing between 100 and $500 \mu \mathrm{g}$ of protein, were used for the assay of CAT activity (Gorman et al. 1982b). For each assay, $0.5 \mu \mathrm{Ci}$ of $\left[{ }^{14} \mathrm{C}\right]$ chloramphenicol $(50 \mathrm{mCi} / \mathrm{mmole}$, Amersham $)$ was used. Following chromatograpy, the TLC plate was autoradiographed overnight, the positions of $\left[{ }^{14} \mathrm{C}\right]$ chloramphenicol and its acetylated derivatives identified, cut from the plate, and their radioactivity measured by scintillation counting. The protein content of cell extracts was measured by use of the Bradford colorimetric assay (Bradford 1976).

\section{$\beta$-Galactosidase assay}

$\beta$-Galactosidase was assayed by use of $\alpha$-nitrophenyl- $\beta-D$ galactopyranoside (Herbomel et al. 1984). $\beta$-Galactosidase (Sigma) was used as a standard, and activities were calculated as milliunits per milligram of protein.

\section{Acknowledgments}

We thank David Conkie for the MELC line 707 B10/1 and Alain Townsend for the mouse myeloma cell line NSO. We also thank Tom Maniatis for pSP6H $\alpha 132$ and pSP64M $\alpha$, Bernie Morley for pSP64H 3135 , John Bennett for pSP64H 110 , Peter Ratcliffe for the rat actin probe, Doug Higgs for $\mathrm{C} \alpha 3^{\prime} \mathrm{Bg}$, Richard Axel for the hamster APRT gene, Kathleen Weston for pV473ßGTlg3, Joan Devine for the virally promoted CAT constructs, and J. Morgenstern for pIRV. We also thank Walter Schaffner for his helpful suggestions and the OVEC series of plasmids. We are also grateful to Gerry Warner and Roger Belcher for their considerable help with the design and construction of the electroporation apparatus and to Linda Roberts and Liz Rose for typing the manuscript. This work was supported by the Medical Research Council (MRC). P.L.C. is in receipt of a MRC training fellowship.

The publication costs of this article were defrayed in part by payment of page charges. This article must therefore be hereby marked "advertisement" in accordance with 18 USC section 1734 solely to indicate this fact.

\section{References}

Alitalo, R., T.P. Makela, P. Koskinen, L.C. Andersson, and K. Alitalo. 1988. Enhanced expression of transforming growth factor $\beta$ during megakaryoblastic differentiation of K562 leukemia cells. Blood 71: 899-906.

Antoniou, M., E. deBoer, G. Habets, and F. Grosveld. 1988. The human $\beta$-globin gene contains multiple regulatory regions: Identification of one promoter and two downstream enhancers. EMBO I. 7:377-384.

Auffray, C. and F. Rougeon. 1980. Purification of mouse immunoglobulin heavy-chain messenger RNAs from total myeloma tumor RNA. Eur. J. Biochem. 107: 303-314.

Bagchi, S., P. Raychaudhuri, and J.R. Nevins. 1989. Phosphorylation-dependent activation of the adenovirus-inducible E2F transcription factor in a cell-free system. Proc. Natl. Acad. Sci. 86: $4352-4356$.

Banerii, J., S. Rusconi, and W. Schaffner. 1981. Expression of a $\beta$ globin gene is enhanced by remote SV40 sequences. Cell 27: 299-302.

Banerii, J., L. Olson, and W. Schaffner. 1983. A lymphocyte-specific cellular enhancer is located downstream of the joining region in immunoglobulin heavy chain genes. Cell 33: 729740.

Baron, M.H. and T. Maniatis. 1986. Rapid reprogramming of globin gene expression in transient heterokaryons. Cell 46: $591-602$.

Behringer, R.R., R.E. Hammer, R.L. Brinster, R.D. Palmiter, and T.M. Townes. 1987. Two $3^{\prime}$ sequences direct adult erythroid-specific expression of human $\beta$-globin genes in transgenic mice. Proc. Natl. Acad. Sci. 84: 7056-7060.

Boggs, S.S., R.G. Gregg, N. Borenstein, and O. Smithies. 1986. Efficient transformation and frequent single-site, singlecopy insertion of DNA can be obtained in mouse erythroleukemia cells transformed by electroporation. Exp. Haematol. 14: 988-994.

Bradford, M.M. 1976. A rapid and sensitive method for the quantitation of microgram quantities of protein utilising the principle of protein-dye binding. Anal. Biochem. 72: 248254.

Chada, K., I. Magram, and F. Costantini. 1987. An embryonic pattern of expression of a human foetal globin gene in transgenic mice. Nature 319: 685-689.

Chao, M.V., P. Mellon, P. Charnay, T. Maniatis, and R. Axel. 
1983. The regulated expression of $\beta$-globin genes introduced into mouse erythroleukemia cells. Cell 32: 483-493.

Charnay, P. and L. Henry. 1986. Regulated expression of cloned human fetal Ay-globin genes introduced into murine erythroleukemia cells. Eur. I. Biochem. 159: 475-478.

Charnay, P., R. Treisman, P. Mellon, M. Chao, R. Axel, and T. Maniatis. 1984. Differences in human $\alpha$ and $\beta$-globin expression in mouse erythroleukemia cells: The role of intragenic sequences. Cell 38: 251-263.

Chen, Z., J. Bank, R.A. Rifkind, and P.A. Marks. 1982. Inducermediated commitment of murine erythroleukemia cells to differentiation: A multistep process. Proc. Natl. Acad. Sci. 79: 471-475.

Cheng, L. and T.J. Kelly. 1989. Transcriptional activator nuclear factor I stimulates the replication of SV40 minichromosomes in vivo and in vitro. Cell 59: 541-551.

Chu, G., H. Hayakawa, and P. Berg. 1987. Electroporation for the efficient transfection of mammalian cells with DNA. Nucleic Acids Res. 15: 1311-1326.

Cisek, L.J. and J.L. Corden. 1989. Phosphorylation of RNA polymerase by the murine homologue of the cell-cycle control protein cdc2. Nature 339: 679-684.

Conkie, D., R.R. Harrison, and J. Paul. 1981. Cell-cycle dependence of induced hemoglobin synthesis in Friend erythroleukemia cells temperature-sensitive for growth. Proc. Natl. Acad. Sci. 78: 3644-3648.

Coppola, J.J. and M.D. Cole. 1986. Constitutive c-myc oncogene expression blocks mouse erythroleukemia cell differentiation but not commitment. Nature 320: 760-763.

Cowie, A. and R.M. Myers. 1988. DNA sequences involved in transcriptional regulation of the mouse $\beta$-globin promoter in murine erythroleukemia cells. Mol. Cell. Biol. 8: 31223128.

de Boer, E., M. Antoniou, V. Mignotte, L. Wall, and F. Grosveld. 1988 . The human $\beta$-globin promoter; nuclear protein factors and erythroid specific induction of transcription. EMBO $J$. 7: 4203-4212.

Deisseroth, A. and D. Hendrich. 1979. Human $\alpha$ globin gene expression following chromosomal dependent gene transfer into mouse erythroleukemia cells. Cell 15: 55-63.

Dynan, W.S. and R. Tiian. 1983. The promoter-specific transcription factor $\mathrm{Spl}$ binds to upstream sequences in the SV40 promoter. Cell 35: 79-87.

Ehrich, E., A. Craig, A. Poustka, A. Frischauf, and H. Lehrach. 1987. A family of cosmid vectors with the multi-copy R6K replication origin. Gene 57: 229-237.

Emerson, B.M. and G. Felsenfeld. 1984. Specific factor conferring nuclease hypersensitivity at the $5^{\prime}$ end of the chicken adult $\beta$-globin gene. Proc. Natl. Acad. Sci. 81: 95-99.

Enver, T., A.C. Brewer, and R.K. Patient. 1988. Role for DNA replication in $\beta$-globin gene activation. Mol. Cell. Biol. 8: $1301-1308$.

Faletto, D.L., A.S. Arrow, and I.G. Macara. 1985. An early decrease in phosphatidylinositol turnover occurs on induction of Friend cell differentiation and precedes the decrease in c-myc expression. Cell 43: 315-325.

Friend, C., W. Scher, J.G. Holland, and T. Sato. 1971. Hemoglobin synthesis in murine virus induced leukemic cells in vitro: Stimulation of erythroid differentiation by dimethyl sulfoxide. Proc. Natl Acad. Sci. 68: 378-382.

Ganguly, S. and A.I. Skoultchi. 1985. Absolute rate of globin gene transcription and mRNA formation during differentiation of cultured mouse erythroleukemia cells. J. Biol. Chem. 260: $12167-12173$.

Gorman, C.M., G.T. Merlino, M.C. Willingham, I. Pastan, and B.H. Howard. 1982a. The Rous sarcoma virus long terminal repeat is a strong promoter when introduced into a variety of eukaryotic cells by DNA-mediated transfection. Proc. Natl. Acad. Sci. 79: 6777-6781.

Gorman, C.M., L.F. Moffat, and B.H. Howard. 1982b. Recombinant genomes which express chloramphenicol acetyltransferase in mammalian cells. Mol. Cell. Biol. 2: 1044-1051.

Graves, B.J., P.F. Johnson, and S.L. McKnight. 1986. Homologous recognition of a promoter domain common to the MSV LTR and the HSV tk gene. Cell 44: 565-572.

Greenberg, M.E., A.L. Hermanowski, and E.B. Ziff. 1986. Effect of protein synthesis inhibitors on growth factor activation of c-fos, c-myc and actin gene expression. Mol. Cell. Biol. 6: $1050-1057$.

Grosschedl, R. and D. Baltimore. 1985. Cell-type specificity of immunoglobulin gene expression is regulated by at least three DNA sequence elements. Cell 41: 885-897.

Grosveld, F., G.B. van Assendelft, D.R. Greaves, and G. Kollias. 1987. Position-dependent high-level expression of the human $\beta$-globin gene in transgenic mice. Cell 51: 975-985.

Gusella, J.F., R. Geller, B. Clarke, V. Weeks, and D. Houseman. 1976. Commitment to erythroid differentiation by Friend erythroleukemia cells: A stochastic analysis. Cell 9: 221229.

Hanscombe, O., M. Vidal, J. Kaeda, L. Luzzatto, D.R. Greaves, and F. Grosveld. 1989. High-level, erythroid-specific expression of the human $\alpha$-globin gene in transgenic mice and the production of human hemoglobin in murine erythrocytes. Genes Dev. 3: $1572-1581$.

Herbomel, P., B. Bourachot, and M. Yaniv. 1984. Two distinct enhancers with different cell specificities coexist in the regulatory region of polyoma. Cell 39: 653-662.

Hiebert, S.W., M. Lipp, and J.R. Nevins. 1989. ElA-dependent trans-activation of the human MYC promoter is mediated by the E2F factor. Proc. Natl. Acad. Sci. 86: 3594-3598.

Higgs, D.R., M.A. Vickers, A.O.M. Wilkie, I.M. Pretorius, A.P. Jarman, and D.J. Weatherall. 1989. A review of the molecular genetics of the $\alpha$-globin gene cluster. Blood 73: 10811104 .

Hill, D.E., I.A. Hope, J.P. Macke, and K. Struhl. 1986. Saturation mutagenesis of the yeast his 3 regulatory site: Requirements for transcripional induction and for binding by GCN4 activator protein. Science 234: 401-516.

Hoheisel, J. and F.M. Pohl. 1986. Simplified preparation of unidirectional clones. Nucleic Acids Res. 14: 3605.

Humphries, R.K., T. Ley, P. Turner, A.D. Moulton, and A.W. Nienhuis. 1982. Differences in human $\alpha-, \beta-$ and $\Delta$-globin gene expression in monkey kidney cells. Cell 30: 173-183.

Jackson, S.P. and R. Tjian. 1988. O-glycosylation of eukaryotic transcription factors: Implications for mechanisms of transcriptional regulation. Cell 55: 125-133.

Kaneda, T., T. Murate, M. Sheffrey, K. Brown, R.A. Rifkind, and P.A. Marks. 1985. Gene expression during terminal differentiation: Dexamethasone suppression of inducer-mediated

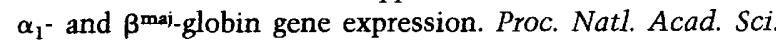
82: $5020-5024$.

Kollias, G., N. Wrighton, J. Hurst, and F. Grosveld. 1986. Regulated expression of human $\mathrm{A}^{\gamma-}, \boldsymbol{\beta}$ - and hybrid $\gamma \beta$-globin genes in transgenic mice: Manipulation of the developmental expression patterns. Cell 46: 89-94.

Kollais, G., J. Hurst, E. deBoer, and F. Grosveld. 1987. The human $\beta$-globin gene contains a downstream developmental specific enhancer. Nucleic Acids Res. 14: 5739-5747.

Kulozik, A.E., N. Yarwood, and R.W. Jones. 1988. The Corfu $\Delta \beta^{\circ}$ thalassaemia: A small deletion acts at a distance to selectively abolish $\beta$ globin gene expression. Blood 71: 457462. 
Laimins, L.A., G. Khoury, C. Gorman, B. Howard, and P. Gruss. 1982. Host-specific activaton of transcription by tandem repeats from simian virus 40 and Moloney murine sarcoma virus. Proc. Natl. Acad. Sci. 79: 6453-6457.

Lee, F., R. Mulligan, P. Berg, and G. Ringold. 1981. Glucocorticoids regulate expression of dihydrofolate reductase cDNA in mouse mammary tumour virus chimaeric plasmids. $\mathrm{Na}$ ture 294: 228-232.

Lee, J.M. and A.L. Greenleaf. 1989. A protein kinase that phosphorylates the C-terminal repeat domain of the largest subunit of RNA polymerase II. Proc. Natl. Acad. Sci. 86: 36242638.

Lowy, I., A. Pelliar, J.F. Jackson, G.-K. Sim, S. Silverstein, and R. Axel. 1980. Isolation of transforming DNA: Cloning the hamster APRT gene. Cell 22: 817-823.

Maniatis, T., E.F. Fritsch, and J. Sambrook. 1982. Molecular cloning: A laboratory manual. Cold Spring Harbor Laboratory Press, Cold Spring Harbor, New York.

Marks, P.A. and R.A. Rifkind. 1989. Induced differentiation of erythroleukemia cells by hexamethylene bisacetamide: A model for cytodifferentiation of transformed cells. Environ. Health Perspect. 80: 181-188.

McKnight, S.L. 1980. The nucleotide sequence and transcript map of the herpes simplex virus thymidine kinase gene. $\mathrm{Nu}$ cleic Acids Res. 8: 5949-5964.

McKnight, S.L., E.R. Gavis, R. Kingsburg, and R. Axel. 1984. Analysis of transcriptional regulatory signals of the HSV thymidine kinase gene: Identification of an upstream control region. Cell 25: 385-398.

Mellon, P., V. Parker, Y. Ghizman, and T. Maniatis. 1981. Identification of DNA sequences required for transcription of the human $\alpha_{1}$-globin gene in a new SV40 host-vector system. Cell 27: 279-288.

Melloni, E., S. Pontremoli, M. Michetti, O. Sacco, A.G. Cakiroglu, J.F. Jackson, R.A. Rifkind, and P.A. Marks. 1987. Protein kinase $\mathrm{C}$ activity and hexamethylene bisacetamide induced erythroleukemia cell differentiation. Proc. Natl. Acad. Sci. 84: 5282-5286.

Melton, D.A., P.A. Krieg, M.R. Rebagliati, T. Maniatis, K. Zinn, and M.R. Green. 1984. Efficient in vitro synthesis of biologically active RNA and RNA hybridization probes from plasmids containing a bacteriophage SP6 promoter. Nucleic Acids Res. 12: 7035-7056.

Muller, M.M., R. Siegfried, W. Schaffner, and P. Matthias. 1988. A cloned octamer transcription factor stimulates transcription from lymphoid-specific promoters in non-B cells. $\mathrm{Na}$ ture 336: 544-551.

Nandi, A.K., R.S. Roginski, R.G. Gregg, O. Smithies, and A.I. Skoultchi. 1988. Regulated expression of genes inserted at the human chromosome $\beta$-globin locus by homologous recombination. Proc. Natl. Acad. Sci. 85: 3845-3849.

Neuberger, M.S. 1983. Expression and regulation of immunoglobulin heavy chain gene transfected into lymphoid cells. EMBO I. 2: 1373-1378.

Nicholls, R.D., N. Fischel-Ghodsian, and D.R. Higgs. 1987. Recombination at the human $\alpha$-globin gene cluster: Sequence features and topological constraints. Cell 49: 369-378.

Nudel, U., R. Zakut, M. Shani, S. Neuman, Z. Levy, and D. Yaffe. 1983. The nucleotide sequence of the rat cytoplasmic $\beta$-actin gene. Nucleic Acids Res. 11: 1759-1771.

Papayannopoulou, T., M. Brice, and G. Stamatoyannopoulos. 1986. Analysis of human hemoglobin switching in MEL $\times$ human fetal erythroid cell hybrids. Cell 46: 469476.

Picard, D. and W. Schaffner. 1985. Cell-type preference of immunoglobulin $\kappa$ and $\lambda$ gene promoters. EMBO J. 4: 2831-
2833.

Profous-Juchelka, H.R., R.C. Reuben, P.A. Marks, and R.A. Rifkind. 1983. Transcriptional and post-transcriptional regulation of globin gene accumulation in induced murine erythroleukemia cells. Mol. Cell. Biol. 3: 229-232.

Ramsay, R.G., K. Ikeda, R.A. Rifkind, and P.A. Marks. 1986. Changes in gene expression associated with induced differentiation of erythroleukemia: Protooncogenes, globin genes and cell division. Proc. Natl. Acad. Sci. 83: 6849-6853.

Raychaudhuri, P., S. Bagchi, and J.R. Nevins. 1989. DNAbinding activity of the adenovirus-induced E4F transcription factor is regulated by phosphorylation. Genes Dev. 3: 620627.

Razin, A., A. Levine, T. Kafri, S. Agostini, T. Gorni, and G.L. Contoni. 1988. Relationship between transient DNA hypomethylation and erythroid differentiation of murine erythroleukemia cells. Proc. Natl. Acad. Sci. 85: 9003-9006.

Rutherford, T., J.B. Clegg, D.R. Higgs, R.W. Jones, J. Thompson, and D.J. Weatherall. 1981. Embryonic erythroid differentiation in the human leukemic cell line K562. Proc. Natl. Acad. Sci. 78: 348-352.

Ryan, T.M., R.R. Behringer, T.M. Townes, R.D. Palmiter, and R.L. Brinster. 1989a. High-level erythroid expression of human $\alpha$-globin genes in transgenic mice. Proc. Natl. Acad. Sci. 86: 37-41.

Ryan, T.M., R.R. Behringer, N.C. Martin, T.M. Townes, R.D. Palmiter, and R.L. Brinster. 1989b. A single erythroid-specific DNase I super-hypersensitive site activates high levels of human $\beta$-globin gene expression in transgenic mice. Genes Dev. 3: 314-323.

Salditt-Georgieff, M., M. Sheffery, K. Krauter, J.E. Darnell, Jr., R. Rifkind, and P.A. Marks. 1984. Induced transcription of the mouse $\beta$-globin transcription unit in erythroleukemia cells. J. Mol. Biol. 172: 437-450.

Sen, R. and D. Baltimore. 1986. Inducibility of $\kappa$ immunoglobulin enhancer-binding protein $\mathrm{NF} \mathrm{B}$ by a posttranslational mechanism. Cell 47: 921-928.

Sheffery, M., P.A. Marks, and R.A. Rifkind. 1984. Gene expression in murine erythroleukemia cells. J. Mol. Biol. 172: $417-436$.

Siebert, P.D. and M. Fukuda. 1985. Regulation of glycophorin gene expression by a tumor-promoting phorbol ester in human leukemic K562 cells. J. Biol. Chem. 260: 640-645.

Smale, S.T. and D. Baltimore. 1989. The "initiator" as a transcriptional control element. Cell 57: 103-113.

Sorger, P.K. and H.R.B. Pelham. 1988. Yeast heat shock factor is an essential DNA-binding protein that exhibits temperature-dependent phosphorylation. Cell 54: 855-864.

Sorger, P.K., M.J. Lewis, and H.R.B. Pelham. 1987. Heat shock factor is regulated differently in yeast and HeLa cells. $\mathrm{Na}$ ture 326: 81-84.

Tabilio, A., P.G. Pelicci, G. Vinci, P. Mannoni, C.I. Civin, W. Vainchenker, Y. Testa, M. Lipinski, H. Rochant, and J. Breton-Gorius. 1983. Myeloid and megakaryocytic properties of K562 cell lines. Cancer Res. 43: 4569-4574.

Talbot, D., P. Collis, M. Antoniou, M. Vidal, F. Grosveld, and D.R. Greaves. 1989. A dominant control region from the human $\beta$-globin locus conferring integration site-independent gene expression. Nature 338: 352-355.

Townes, T.M., J.B. Lingrel, H.Y. Chen, R.L. Brinster, and R.D. Palmiter. 1985. Erythroid-specific expression of human $\beta$ globin genes in transgenic mice. EMBO J. 4: 1715-1723.

Treisman, R., M.R. Green, and T. Maniatis. 1983. Cis and trans activation of globin gene transcription in transient assays. Proc. Natl. Acad. Sci. 80: 7428-7432.

Trudel, M., J. Magram, L. Bruckner, and F. Constantini. 1987. 


\section{Campbell et al.}

Upstream of ${ }^{{ }^{C}} \gamma$-globin sequences required for stage-specific expression in transgenic mice. Mol. Cell. Biol. 7: 40244029.

Tsai, S., D.I.K. Martin, L.I. Zon, A.D. D'Andrea, G.G. Wong, and S.H. Orkin. 1989. Cloning of cDNA for the major DNAbinding protein of the erythroid lineage through expression in mammalian cells. Nature 339: 446-451.

Tuan, D.Y.H., W.G. Soloman, I.M. London, and D.P. Lee. 1989. An erythroid-specific, developmental-stage-independent enhancer from upstream of the human " $\beta$-like globin" genes. Proc. Natl. Acad. Sci. 86: 2554-2558.

van Assendelft, G.B., O. Hanscombe, F. Grosveld, and R. Greaves. 1989. The $\beta$-globin dominant control region activates homologous and heterologous promoters in a tissuespecific manner. Cell 56: 969-977.

Volloch, V. and D. Housman. 1981. Stability of globin mRNA in terminally differentiating murine erythroleukemia cells. Cell 23: 509-514.

Wall, L., E. de Boer, and F. Grosveld. 1988. The human $\beta$-globin gene $3^{\prime}$ enhancer contains multiple binding sites for an erythroid-specific protein. Genes Dev. 2: 1089-1100.

Westin, G., T. Gerster, M.M. Muller, G. Schaffner, and W. Schaffner. 1987. OVEC, a versatile system to study transcription in mammalian cells and cell-free extracts. Nucleic Acids Res. 15: 6787-6798.

Whitelaw, E., P. Hogben, O. Hanscombe, and N.J. Proudfoot. 1989. Transcriptional promiscuity of the human $\alpha$-globin gene. Mol. Cell. Biol. 9: 241-251.

Workman, J.L. and R.G. Roeder. 1987. Binding of transcription factor TF II D to the major late promoter during in vitro nucleosome assembly potentiates subsequent initiation by RNA polymerase II. Cell 51: 613-622.

Workman, J.L., S.M. Abmayr, W.A. Cromlish, and R.G. Roeder. 1988. Transcriptional regulation by the immediate early protein of pseudorabies virus during in vitro nucleosome assembly. Cell 55: 211-219.

Wright, S., E. deBoer, F.G. Grosveld, and R.A. Flavell. 1983. Regulated expression of the human $\beta$-globin gene family in murine erythroleukemia cells. Nature 305: 333-336.

Wright, S., A. Rosenthal, R. Flavell, and F. Grosveld. 1984. DNA sequences required for regulated expression of $\beta$ globin genes in murine erythroleukemia cells. Cell 38: $265-$ 273.

Yamamoto, K.K., G.A. Gonzalez, W.H. Biggs III, and M.R. Montminy. 1988. Phosphorylation-induced binding and transcriptional efficacy of nuclear factor CREB. Nature 334: 494-498. 


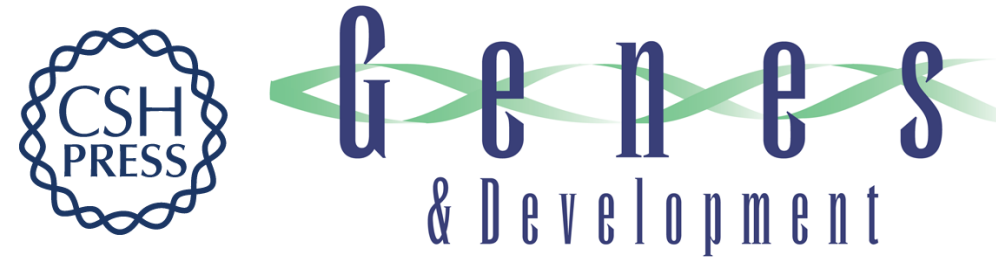

\section{Induction by HMBA and DMSO of genes introduced into mouse erythroleukemia and other cell lines by transient transfection.}

P L Campbell, A E Kulozik, J P Woodham, et al.

Genes Dev. 1990, 4:

Access the most recent version at doi:10.1101/gad.4.7.1252

References This article cites 96 articles, 34 of which can be accessed free at: http://genesdev.cshlp.org/content/4/7/1252.full.html\#ref-list-1

License

Email Alerting Service right corner of the article or click here.

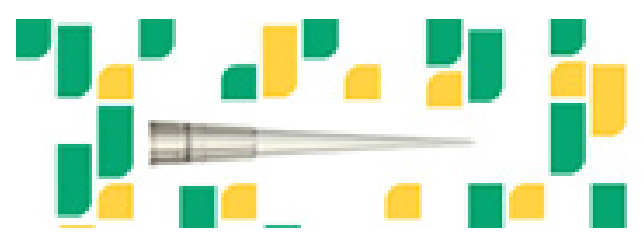

